\title{
Alternative Tourism and Environmental Impacts: Perception of Residents of an Extractive Reserve in the Brazilian Amazonia
}

\author{
Heloise Michelle Nunes Medeiros ${ }^{1,2, *}$, Quêzia Leandro de Moura Guerreiro ${ }^{2}$, Thiago Almeida Vieira 1,3 $\mathbb{D}$, \\ Sandra Maria Sousa da Silva ${ }^{4}$, Ana Isabel da Silva Aço Renda ${ }^{5}$ D and José Max Barbosa Oliveira-Junior ${ }^{1,2, *(D)}$ \\ 1 Programa de Pós-Graduação em Sociedade, Ambiente e Qualidade de Vida (PPGSAQ), \\ Universidade Federal do Oeste do Pará (UFOPA), Rua Vera Paz, s/n (Unidade Tapajós) Bairro Salé, \\ Santarém 68040-255, Brazil; thiago.vieira@ufopa.edu.br \\ 2 Instituto de Ciências e Tecnologia das Águas (ICTA), Universidade Federal do Oeste do Pará (UFOPA), \\ Rua Vera Paz, s/n (Unidade Tapajós) Bairro Salé, Santarém 68040-255, Brazil; queziamoura@hotmail.com \\ 3 Instituto de Biodiversidade e Florestas (IBEF), Universidade Federal do Oeste do Pará (UFOPA), \\ Rua Vera Paz, s/n (Unidade Tapajós) Bairro Salé, Santarém 68040-255, Brazil \\ 4 Centro de Formação Interdisciplinar (CFI), Universidade Federal do Oeste do Pará (UFOPA), Rua Vera Paz, \\ s/n (Unidade Tapajós) Bairro Salé, Santarém 68040-255, Brazil; sandra.silva@ufopa.edu.br \\ 5 Escola Superior de Gestão, Hotelaria e Turismo (ESGHT), Universidade do Algarve (UAlg), \\ Campus da Penha, Estrada da Penha, 8000 Faro, Portugal; arenda@ualg.pt \\ * Correspondence: heloise_medeiros28@hotmail.com (H.M.N.M.); jose.mbo@ufopa.edu.br (J.M.B.O.-J.)
}

check for updates

Citation: Medeiros, H.M.N.; Guerreiro, Q.L.d.M.; Vieira, T.A.; Silva, S.M.S.d.; Renda, A.I.d.S.A.; Oliveira-Junior, J.M.B. Alternative Tourism and Environmental Impacts: Perception of Residents of an Extractive Reserve in the Brazilian Amazonia. Sustainability 2021, 13 , 2076. https://doi.org/10.3390/su 13042076

Academic Editor: Brian Garrod

Received: 16 January 2021

Accepted: 10 February 2021

Published: 15 February 2021

Publisher's Note: MDPI stays neutral with regard to jurisdictional claims in published maps and institutional affiliations.

Copyright: (c) 2021 by the authors. Licensee MDPI, Basel, Switzerland. This article is an open access article distributed under the terms and conditions of the Creative Commons Attribution (CC BY) license (https:// creativecommons.org/licenses/by/ $4.0 /)$.

\begin{abstract}
Alternative tourism (AT) contributes to conservation, valuing the environment and recipient cultures with minimal impact, especially in protected areas. In this context, this article identified, considering the residents' perception, the possible environmental impacts resulting from alternative tourism in communities of the Tapajós-Arapiuns Extractive Reserve (RESEX), Brazilian Amazonia. Thus, between February and April 2019 a semi-structured interview was conducted with 122 residents of three communities of RESEX (Anã, Maripá, and São Miguel). The interview script was divided into three groups of questions: (i) interviewee data, (ii) socioeconomic data, and (iii) perception of the concept and environmental impacts of alternative tourism. We used a snowball sampling method, which consists of a form of a non-probabilistic sample. The majority (91.8\%) of the informants did not know how to explain the concept of alternative tourism; however, for $87.7 \%$ of them, this tourism does not generate negative impacts. Income is the most used expression (53\%) by RESEX residents to demonstrate what alternative tourism positively impacts. About $74.6 \%$ of respondents reported that tourists do not influence local customs change, and $94.3 \%$ do not identify tourism-related violence. Finally, 89.3\% say that tourists do not pollute the environments. The research carried out in this Conservation Unit deserves the attention of decision-makers, managers, technicians, and researchers. It provides subsidies for management programs to provide real bases for the analysis, interpretation, and planning of sustainable tourist spaces.
\end{abstract}

Keywords: Amazonia; ecotourism; environmental impacts; conservation unit; environmental perception

\section{Introduction}

The negative impacts caused by mass tourism and the inequalities linked to traditional tourist activities strongly influenced the emergence of new types of tourism, whose origin is also closely related to the human being's desire to reconnect with their origins, enjoy natural environments, and the awakening of a greater environmental awareness. Consequently, alternative tourism gains visibility in this new perspective, as it encourages participation in recreational activities in contact with nature and cultural expressions, respecting the natural, cultural, and historical heritage of the place visited. In the search for more responsible tourism options, alternative tourism is promoted as an activity that positively affects local development [1]. 
Alternative tourism incorporates all stakeholders' long-term interest and the quality of the phenomenon, considering local human communities, their environment, and natural resources [2]. It can be divided into categories such as, among others, nature tourism, ecotourism, rural tourism, community-based tourism, agrotourism, voluntary tourism, responsible tourism, geotourism, adventure tourism, soft tourism, sustainable tourism, small-scale tourism, green tourism, integrated tourism, cultural tourism, and creative tourism [2-7], with alternative purposes to the most undesired type of tourism, which is mass tourism or conventional/traditional tourism, with characteristics and approaches for developing harmonic and sustainable tourism [4,6].

Alternative tourism presents itself as an option for developing small-scale recreational activities in communities or places where it is possible to control the negative impacts of the tourist phenomenon. It can contribute to local development, given the possibilities of establishing networks and intersectoral relationships between actors related directly or indirectly to tourism, and an alternative to generating income produced locally, thus benefiting the local community [4].

There are several definitions and concepts for alternative tourism; however, there is a common aspect, that is, a type of tourism that presents a closer relationship with nature, a concern with the conservation of natural and social resources in the areas where it is developed. This tourist segment seeks to comply with the responsible use of existing natural resources, generating equitable economic development and benefits that promote an increase in local inhabitants' quality of life, causing the least negative impact on their resources and the maximum expected benefit. Therefore, alternative tourism involves trips that do recreational activities in direct contact with nature and cultural expressions with attitudes and commitments to know, respect, enjoy, and participate in conserving natural and cultural resources [8].

Among the characteristics commonly related to alternative tourism are (i) low-density and small-scale accommodation, based on local styles, owned and operated locally; (ii) lowvolume market, with flows all year round, from different sources in search of knowledge; (iii) economy that complements other sectors generating a multiplier effect; (iv) local control, with public sector and community involvement [5]. This segment is mostly carried out in specially protected territories such as Conservation Units (UC), where wildlife concentrate and are easier to observe [9].

Protected areas were created in the face of urban expansion and the Industrial Revolution, which occurred in the 20th century. They are essential areas chosen for preserving and conserving fauna, flora, and ecosystems [10] and are also relevant in the cultural, economic, and social context $[11,12]$.

Although protected areas have existed in Brazil since 1937, it was only on 18 July 2000, that Federal Law No. 9985 was enacted that created the National System of Conservation Units (SNUC) $[13,14]$. The SNUC is an essential tool for searching for conservation and/or preservation of the environment [12]. The 7th article of that law divides Conservation Units into two groups: Integral Protection Units (with five categories) and Sustainable Use Units (with seven categories).

One of the categories of the second group is the Extractive Reserve (RESEX). This group comprises areas characterized by their sustainable exploitation, performed by traditional extractive populations, who live on extraction and subsistence agriculture, including creating small animals. The RESEX objective is to protect the lifestyle and culture of the resident population, based on sustainable use of the soil [13]. Public visitation is allowed as long as it is provided for in the Management Plan and the scientific research, with prior authorization from the responsible entities for administrating RESEX, and with respect to the conditions and restrictions established by the rules and regulations [13].

In this sense, when developed in these Conservation Units, alternative tourism aims to improve the quality of life of local populations and ensure compliance with the principles of sustainable development, environmental education, and minimizing environmental impacts. Furthermore, it effectively attracts locations with great natural potential and an 
essential environmental conservation instrument $[12,15]$. In the Amazonia, the largest world biological reserve [16], this practice may be one of the best sustainable development alternatives.

Even with all planning, tourism can still cause negative impacts that must be managed [17]. The presence of pet bottles, plastic packages left by tourists, cut trees, fallen trees, and the lack of adequate signs on the trails can be presented as good examples to demonstrate a lack of planning and inspection by managers [18].

The negative or positive impacts arising from tourism activity are related, at first, to potential damage to the natural environment and the community. However, if well managed, ecotourism activity presupposes socioeconomic and environmental benefits expected from the local to the national level. Those benefits can be improvements such as diversification of the regional economy, local jobs, non-emigration to cities, transport, communications and sanitation infrastructures, increased collection alternatives for Conservation Units, mitigation of impacts on the natural, cultural, and aesthetic landscape, and improvement of equipment in protected areas [19].

The community should receive technical assistance by the local government to manage these impacts [20]; it is crucial to identify how the residents' communities perceive the tourism impacts.

Environmental perception includes social environment, life history, education level, religious beliefs, and economic activity through the interaction between human beings, and between them and nature [21]. In the same way, each individual defines his mode of relationship with society, which can also reflect a collective understanding [22].

Understanding perception is essential for planning various activities that will impact individuals' lives [23]. Local perception of tourist activities is necessary to understand how such tourism is organized and how the residents participate in the activity [20].

Several studies have evaluated tourism in protected areas in Brazil [24,25]. However, still no studies seek to identify the possible environmental impacts of alternative tourism, in the perception of residents the Conservation Unit in the Brazilian Amazonia. In the case of the RESEX Tapajós-Arapiuns, an important Conservation Unit in the Northern region of Brazil, created with proposals, among others, to combat deforestation in the Brazilian Amazonia, it is salutary to know how residents visualize the environmental impacts resulting from tourism. This activity is developing in some communities to subsidize future public policies. In this context, this article identified, considering the perception of residents, the possible environmental impacts resulting from alternative tourism in RESEX Tapajós-Arapiuns communities, State of Pará, Brazilian Amazonia.

\section{Materials and Methods}

\subsection{Study Area}

The study was carried out in three communities (Anã, Maripá, and São Miguel) located at RESEX Tapajós-Arapiuns, created in November 1998, and has approximately 647,610 ha of territorial extension, of which $66 \%$ belong to the municipality of Santarém and $34 \%$ to the municipality of Aveiro, both in the state of Pará, Brazil (Figure 1). Its limits are marked as follows: east by the Tapajós river; west by the Maró river; north by the Arapiuns river; and south by the Escrivão community [26].

\subsubsection{Environmental Characterization}

According to the climatic classification described by the Köppen method, the Santarém region falls into the "Am" group, characterized by a moderate dry season and high annual rainfall [27]. Annual rainfall ranges from 1900 to $2100 \mathrm{~mm}$, and there are two distinct periods, rainy (from December to May) and dry (from July to November) [28]. The high temperatures present an annual average variation between $25^{\circ} \mathrm{C}$ and $28{ }^{\circ} \mathrm{C}$, with high relative humidity (average of $86 \%$ ), characteristic of the tropical forests [29].

RESEX Tapajós-Arapiuns covers 13 main hydrographic basins, totaling an area of $6760.6 \mathrm{~km}^{2}$, of which the Tapajós, Arapiuns, Maró, Aruã, Inhambú, and São Pedro rivers 
stand out. The rainy season period influences rivers' dynamics in floods and ebbs [30-32]. The Tapajós and Arapiuns rivers' waters have a clear hue, usually accentuated during the dry season [32]. Access is mainly by the river, which can be from the port of Santarém, Aveiro, and the District of Alter do Chão.

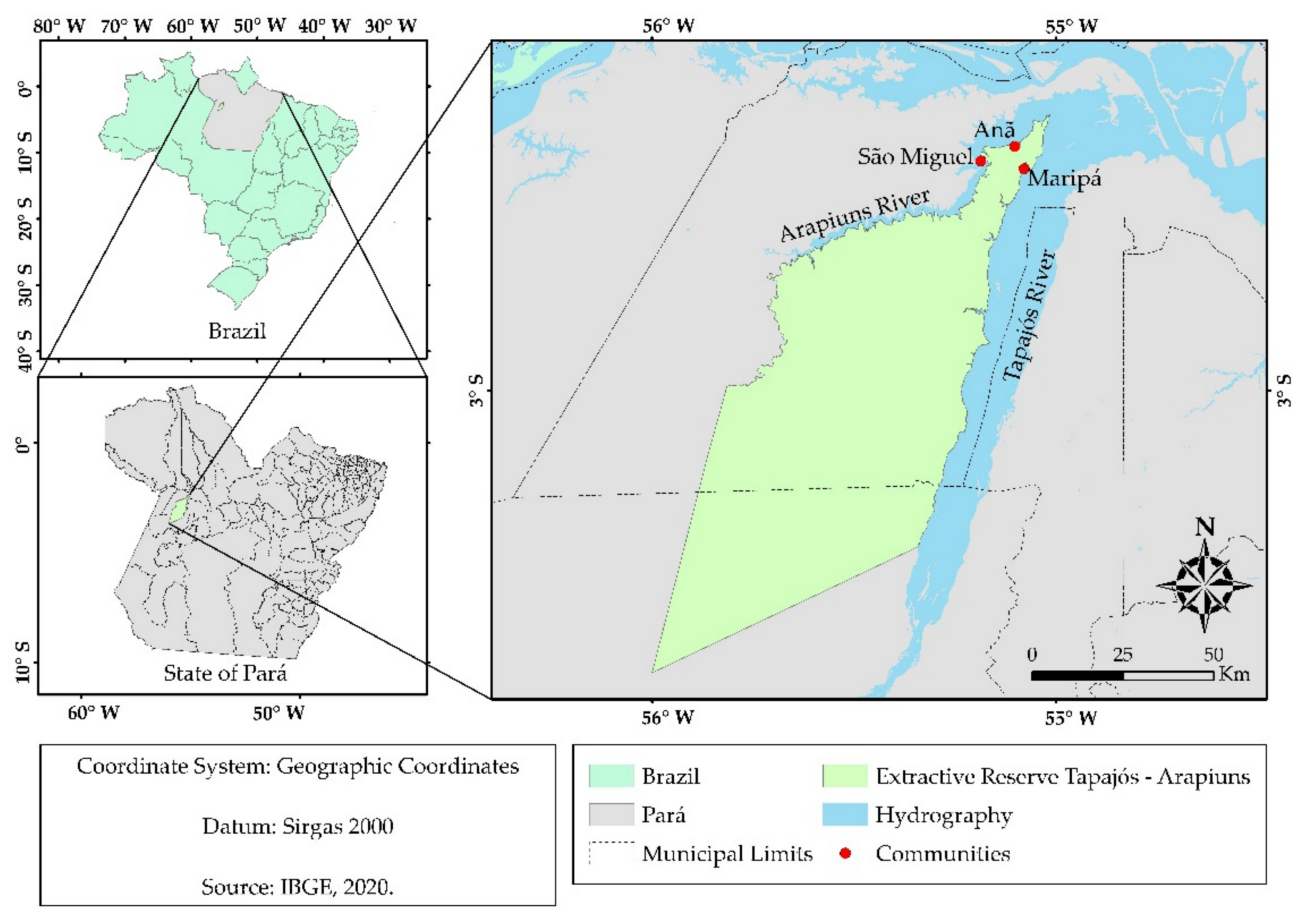

Figure 1. Location of the communities studied at the RESEX Tapajós-Arapiuns, State of Pará (PA), Brazil (SIRGAS 2000).

The soil types identified in the RESEX Tapajós-Arapiuns are as follows: (1) Yellow Argisols, located in the eastern portion; (2) the Red-Yellow Argisols found in a small portion in the southernmost part; (3) the Yellow Latosols that cover most of the conservation unit; (4) and the Neossolo Flúvico Distrófico that occupies the entire drainage of the Inhambú River [33]. The altimetry in this reserve varies between the altitudes of $2 \mathrm{~m}$ to $216 \mathrm{~m}$, the smallest (2 to $51 \mathrm{~m}$ ) area can be found in the eastern portion of the banks of the Tapajós River and northwest area, already the highest altitudes (153 to $261 \mathrm{~m}$ ) then in the central-eastern region of the Conservation Unit [34].

The predominant vegetation typology at RESEX Tapajós-Arapiuns is the Dense Ombrophylous Forest, which occurs in $88 \%(591,420.00 \mathrm{ha})$ of the area. This phytophysiognomy is characterized by the abundance of large trees, the presence of woody lianas (vines and climbing plants), and epiphytes (plants that attach themselves to other plants or surfaces, such as bromeliads) [35]. The occurrences of the species Bagassa guianensis Aubl., Bertholletia excelsa Bonpl., Dipteryx odorata (Aubl.) Willd., and Hevea brasiliensis (Willd. Ex A. Juss.) Müll Arg. have been recorded; another vegetable typology is the Savanna, which occupies less than 1\% (620 ha) and sometimes occurs as rupestrian fields. There are still igapó forests and secondary vegetation in $3 \%$ of the area $(21,649 \mathrm{ha})$ [32].

\subsubsection{Socioeconomic Characterization}

At RESEX Tapajós-Arapiuns, approximately 4581 extractivists' families live, totaling 27,027 residents distributed in the "urban agglomerations" called villages or communities. Altogether, 74 communities are divided between the channels of the rivers Arapiuns (25) and Tapajós (49) [31,32]. The occupation process took place from the resistance of the huts in the Ecuipiranga region (now Cuipiranga), strategically located between the Arapiuns, Tapajós, and Amazonas rivers. However, the region was taken over by the 
Brazilian empire causing the residents to flee to the Vila de Pinhel (southern region of RESEX Tapajós-Arapiuns, municipality of Aveiro) [35].

Social practices are represented by the celebrations of patron saints of communities and evangelical cults; parties are also held with traditional dances such as marabaixo, sairé, and opossum. In addition, community members organize sports tournaments and local shows for the residents or visitor's leisure [31,32].

As for infrastructure in 2014, RESEX Tapajós-Arapiuns had 7 health posts, 18 public telephones, 64 schools, 67 power generators, 69 community headquarters, 69 churches (Catholic and Evangelical), 69 soccer fields, and reception facilities for tourists. Parts of these structures work poorly due to lack of maintenance [29,30]. RESEX Tapajós-Arapiuns has approximately 45 community or intercommunity associations. These are linked to the Association of Tapajós-Arapiuns Extractive Reserve Organizations (TAPAJOARA), founded in July 1999, considered a general association representing them socially and politically $[31,32]$.

Among the economic activities that generate income for community members are agriculture, the creation of small and large animals, hunting, fishing, handicrafts, tourism, and timber and non-timber extraction, some of which are seasonal and complement each other throughout the year [31,32].

\subsubsection{Description of Sampled Communities}

The communities of Anã, Maripá, and São Miguel were selected for the research, as according to ICMBIO and TAPAJOARA they have the structure to receive tourists. A large part is from Brazilian tourists, coming from other Brazil regions, but foreigners also visit (Table 1).

Table 1. Characterization of the communities Anã, Maripá, and São Miguel located at RESEX Tapajós-Arapiuns, Pará, Brazilian Amazonia.

\begin{tabular}{cccccc}
\hline Communities & $\begin{array}{c}\text { Total } \\
\text { Families }\end{array}$ & $\begin{array}{c}\text { Sampled } \\
\text { Families }\end{array}$ & $\begin{array}{c}\text { Localization } \\
\text { (River) }\end{array}$ & Association & Main Economic Sources \\
\hline Anã & 96 & 35 & Arapiuns & APROANÃ $^{1}$ & Family farming, extractivism, trade, and tourism \\
\hline Maripá & 75 & 46 & Tapajós & ASCOPRAM $^{2}$ & Family farming, extractivism, and tourism \\
\hline São Miguel & 80 & 41 & Arapiuns & ASCOVISM $^{3}$ & Family farming, extractivism, trade, and tourism \\
\hline
\end{tabular}

Adapted from ICMBIO [31,32]; PSA [35]. Legend: ${ }^{1}$ Associação de Produtores Rurais da Comunidade de Anã; ${ }^{2}$ Associação Comunitária de Produtores da Comunidade de Maripá; ${ }^{3}$ Associação Comunitária da Vila de São Miguel.

\subsection{Data Collection}

This case study had an exploratory nature to offer subsidies, insights, and ideas for new investigations on the same theme. This paper investigated residents' perceptions of tourism impacts on an Extractive Reserve in Amazonia, including the role of tourism in the local socioeconomic and environmental damages resulting from tourism. The perceptions of residents regarding the impacts of tourism are essential for planning and for policy actions for developing present and future tourism programs/projects, given the host population has a favorable view of these [36]. Based on the social exchange theory, it is possible to understand how locals perceive tourism impacts, by understanding the exchange of resources between individuals and groups [36].

The research is qualitative and quantitative, and the data were collected through semi-structured interviews with $48.6 \%$ of resident families of the three communities using a script of questions with open and closed questions (between February and April 2019). The interview script was divided into three groups of questions: (i) interviewee data, (ii) socioeconomic profile, and (iii) perception of the concept and of environmental impacts of alternative tourism (see Table S1). 
During the last several decades, interviews have remained the main research method within the social sciences $[37,38]$. Carefully conducted personal interviews can, in certain situations, provide rich data and important insights into phenomena [38,39].

Contacts were established initially with each community leaders to facilitate access and dialogue with extractivist communities. From this moment, a pre-test was carried out in February 2019 to check the flaws in the instrument, the clarity of the questions, the response time, and the respondents' interest in the topic addressed, as well as to guide the sample sizing, as advised by Oliveira [40]. Some respondents in this phase were excluded from the survey. This step resulted in the inclusion of two new questions and small corrections and/or improvements before the final interview.

We used a snowball sampling method, which consists of using a non-probabilistic sample and reference chains, and it is not possible to determine the probability of selection of each participant in the research [41-44]. This selecting informants method is useful in some cases, making it more interesting for the researcher to identify potential informants in a non-random way [45], e.g., when the community is small, when knowledge is not distributed evenly in the community.

People were nominated and effectively selected if they met the following criteria: (i) over 18 years; (ii) living in the communities for at least one year, as they have already been able to verify the dynamics of tourism in these communities; (iii) having contact with tourists through the reception at their homes or accommodation, conducting sales in general, providing services as accompanying tourists in the communities; and (iv) signed the informed consent form (ICF).

The interviews were conducted at the informants' residence or workplace, thus respecting their convenience and acceptance by the interviewee. In each community, a resident was assigned to be the conductor and present the researchers.

\subsection{Data Analysis}

The data obtained in the interviews were tabulated and analyzed using descriptive statistics procedures by calculating the relative frequencies of the answers given to verify the respondents' socioeconomic profile and the impacts perceived by the informants. Microsoft Excel for Windows was used to build tabulation of data and create tables and graphs to demonstrate gender, age, time of residence, ethnical and education aspects, changes in the economy, cultural, social, political, and natural environments.

Similarity analysis was carried out to show the expressions most used by residents to demonstrate what alternative tourism brings with positive impacts on communities. For this purpose, the free software IRAMUTEQ (Interface de R pour lês Analyses Multidimensionnelles de Texte set de Questionnaires) was used. As a computerized method for text analysis, IRAMUTEQ uses the R software structure as the basis for performing calculations and Python programming language.

To assess the distinction between the respondents' responses, they were summarized in a Principal Component Analysis (PCA). The randomness obtained by the Broken-stick model was used to determine which main components should be retained for analysis [46]. This analysis was performed by the R program's routines [47], using vegan and MASS packages.

\section{Results and Discussion}

\subsection{General Description and Socioeconomic Profile}

In total, 122 extractivists were interviewed, of which 35 lived in the community of Anã, 46 in Maripá, and 41 in São Miguel. The most representative gender was female $(69.7 \%)$ (Table 2). A study with fishers from the marine RESEX Ponta do Corumbau, state of Bahia, showed that women take on important positions in communities, as coordinators of nuclei [48]. The study revealed that women's role is crucial in the case of RESEX TapajósArapiuns, in the community of Suruacá. Women participate intensively in the production of 
flour and in the small animal husbandry. In addition, women carry out domestic activities with daughters, daughters-in-law, and granddaughters [49].

Table 2. Socioeconomic profile of extractivists interviewed from three RESEX communities TapajósArapiuns, Pará, Brazilian Amazonia. N. = absolute number.

\begin{tabular}{|c|c|c|c|c|c|c|c|c|}
\hline \multirow{3}{*}{ Socio-Economic Variables } & \multicolumn{6}{|c|}{ RESEX Communities } & \multicolumn{2}{|c|}{ Total } \\
\hline & \multicolumn{2}{|c|}{ Anã } & \multicolumn{2}{|c|}{ Maripá } & \multicolumn{2}{|c|}{ São Miguel } & \multirow[b]{2}{*}{ N. } & \multirow[b]{2}{*}{$\%$} \\
\hline & N. & $\%$ & N. & $\%$ & N. & $\%$ & & \\
\hline \multicolumn{9}{|l|}{ Gender } \\
\hline Female & 18 & 51.4 & 36 & 78.3 & 31 & 75.6 & 85 & 69.7 \\
\hline Male & 17 & 48.6 & 10 & 21.7 & 10 & 24.4 & 37 & 30.3 \\
\hline Total & 35 & 100 & 46 & 100 & 41 & 100 & 122 & 100 \\
\hline \multicolumn{9}{|l|}{ Age groups (in years) } \\
\hline Young $(\leq 19)$ & - & - & 1 & 2.2 & 1 & 2.4 & 2 & 1.6 \\
\hline Adults (20 to 59) & 29 & 82.9 & 35 & 76.1 & 28 & 68.3 & 92 & 75.4 \\
\hline Seniors $(\geq 60)$ & 6 & 17.1 & 10 & 21.7 & 12 & 29.3 & 28 & 23 \\
\hline Total & 35 & 100 & 46 & 100 & 41 & 100 & 122 & 100 \\
\hline \multicolumn{9}{|l|}{ Color/race } \\
\hline Brown & 30 & 85.7 & 42 & 91.3 & 33 & 80.5 & 105 & 86.1 \\
\hline Indigenous & 4 & 11.4 & 3 & 6.5 & 6 & 14.6 & 13 & 10.7 \\
\hline White & 1 & 2.9 & - & - & 2 & 4.9 & 3 & 2.5 \\
\hline Black & - & - & 1 & 2.2 & - & - & 1 & 0.8 \\
\hline Total & 35 & 100 & 46 & 100 & 41 & 100 & 122 & 100 \\
\hline \multicolumn{9}{|l|}{ Residence time (in years) } \\
\hline$\leq 10$ & 5 & 14.3 & 2 & 4.3 & 4 & 9.8 & 11 & 9.0 \\
\hline From 11 to 20 & 3 & 8.6 & - & - & 5 & 12.2 & 8 & 6.6 \\
\hline From 21 to 30 & 9 & 25.7 & 5 & 10.9 & 3 & 7.3 & 17 & 13.9 \\
\hline From 31 to 40 & 6 & 17.1 & 3 & 6.5 & 8 & 19.5 & 17 & 13.9 \\
\hline$\geq 41$ & 12 & 34.3 & 36 & 78.3 & 21 & 51.2 & 69 & 56.6 \\
\hline Total & 35 & 100 & 46 & 100 & 41 & 100 & 122 & 100 \\
\hline \multicolumn{9}{|l|}{ Education } \\
\hline No schooling & 2 & 5.7 & 1 & 2.2 & 4 & 9.8 & 7 & 5.7 \\
\hline Incomplete elementary school & 13 & 37.1 & 21 & 45.7 & 20 & 48.8 & 54 & 44.3 \\
\hline Complete primary education & - & - & 9 & 19.6 & - & - & 9 & 7.4 \\
\hline Incomplete high school & 3 & 8.6 & 2 & 4.3 & 6 & 14.6 & 11 & 9.0 \\
\hline Complete high school & 16 & 45.7 & 9 & 19.6 & 7 & 17.1 & 32 & 26.2 \\
\hline Incomplete higher education & - & - & 2 & 4.3 & - & - & 2 & 1.6 \\
\hline Graduated & 1 & 2.9 & 2 & 4.3 & 4 & 9.8 & 7 & 5.7 \\
\hline Total & 35 & 100 & 46 & 100 & 41 & 100 & 122 & 100 \\
\hline
\end{tabular}

The most pronounced color was brown (86.1\%) (Table 2), which is consistent with the self-declaration of the majority of the population residing in the north of the country [50].

Most respondents lived in the area for more than 41 years (56.6) (Table 2). Although the RESEX Tapajós-Arapiuns was created 21 years ago, the communities have been around from 20 to 300 years. These communities originated from indigenous villages, mainly of the Mayatapu, Tupinambá, and Kumaruara ethnicities, of the Jesuit colonization process, of the Cabano movement, of the rubber cycle, and even more recently, in response to government incentives for agricultural expansion and occupation in the region [51].

As for the level of education, $44.3 \%$ of the interviewees did not complete elementary school (Table 2). The low level of education may be related to the lack of schools in some communities at RESEX or the distance students need to travel to the nearest school. This profile was also identified in the study by Costa and Sobrinho [52], carried out in the State Forest of Amapá (Brazilian Amazonia), where 53\% of the interviewees did not complete 
Elementary School. The works of Guerreiro [53] in the Tapajós National Forest, in the state of Pará, and de Silva et al. [54], at the Piagaçu-Purus Sustainable Development Reserve in the Amazonas' state, corroborate this reality.

The agricultural activity is less sophisticated, which requires less qualified labor demand. The education difference between those employed in the primary sector compared to those working in the secondary and tertiary sectors results in a great inequality of educational opportunities unfavorable to farmers [55]. This fact can also be associated with the difficult access to primary education in the last decades, in addition to the lack of incentive on the part of the relatives of the residents who had day-to-day activities as more important than studies [56,57].

The results showed that about $27 \%$ extractivists worked in agriculture; $25.4 \%$ were retired, and $12.3 \%$ were housewives. In Maripá, the informants' main occupation was agriculture (45.6\%) followed by retirees (15.2\%); in São Miguel and Anã, retirees stood out $(28.9 \%$ and $20 \%$, respectively) (Figure 2). It is important to highlight that none of the interviewees considered tourism as their main source of income. The non-timber forest products extractivism [58] and agriculture [59-61] are the most important actives in Extractive Reserves on Amazonia.

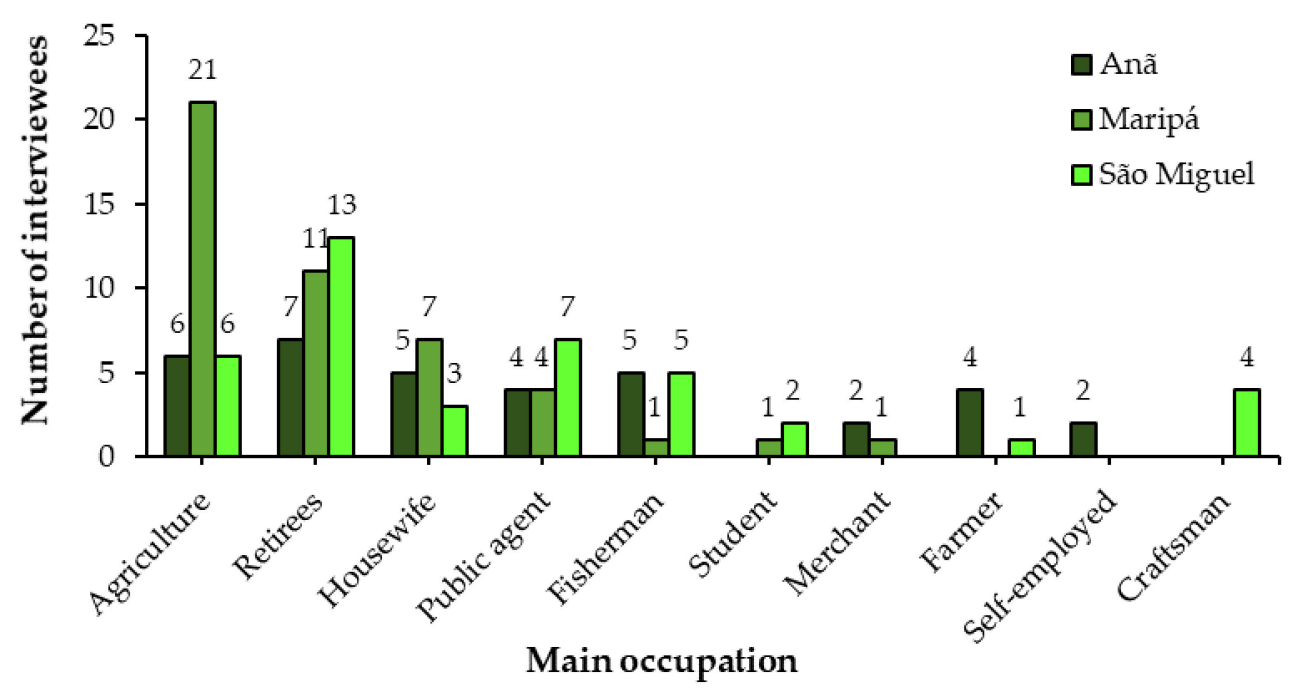

Figure 2. Main occupations of the extractivists interviewed with experience in tourism from three communities of RESEX Tapajós-Arapiuns, Pará, Brazilian Amazonia.

At the Alto Juruá RESEX, 100\% of the interviewed extractivists had agriculture as their primary activity [61], which was also found in the research conducted at the Riozinho do Anfrísio Extractive Reserve with Brazil nut extractives in state of Pará [62], and in RESEX Chico Mendes in state of Acre [63]. The importance of agriculture is due to production for the family's self-consumption, such as cassava, beans, corn, and fruits. Agriculture activities have been in accordance with the management plans of these areas, to reconcile with forest exploitation (of wood and non-timber forest products), and contribute to environmental conservation. The sustainable use of these lands will contribute to the family's subsistence and budget, as well as to the conservation of this important biome.

Rural pensions were among the main sources of income reported (Figure 2) because $25 \%$ of respondents were over 55 years of age.

Anã and São Miguel's monthly income of families ranged from $R \$ 501.00$ to $R \$ 1000.00$; in Maripá, families earned up to $\mathrm{R} \$ 500.00$ (Figure 3). This variation was also observed in the work of Vasconcelos et al. [64], carried out in the Laranjal community in Santarém, state of Pará, where the family income was between $\mathrm{R} \$ 145.00$ and $\mathrm{R} \$ 3500.00$. In this study, the highest salaries were for retirees from the urban area who decided to change for this rural community. The Northern region, as a whole, has a low family income. This situation may be related, according to Salvato et al. [65], with the concentration of people with a low 
level of education (human capital) and few tools (physical capital), requiring education and professional qualification policies and credit access programs.

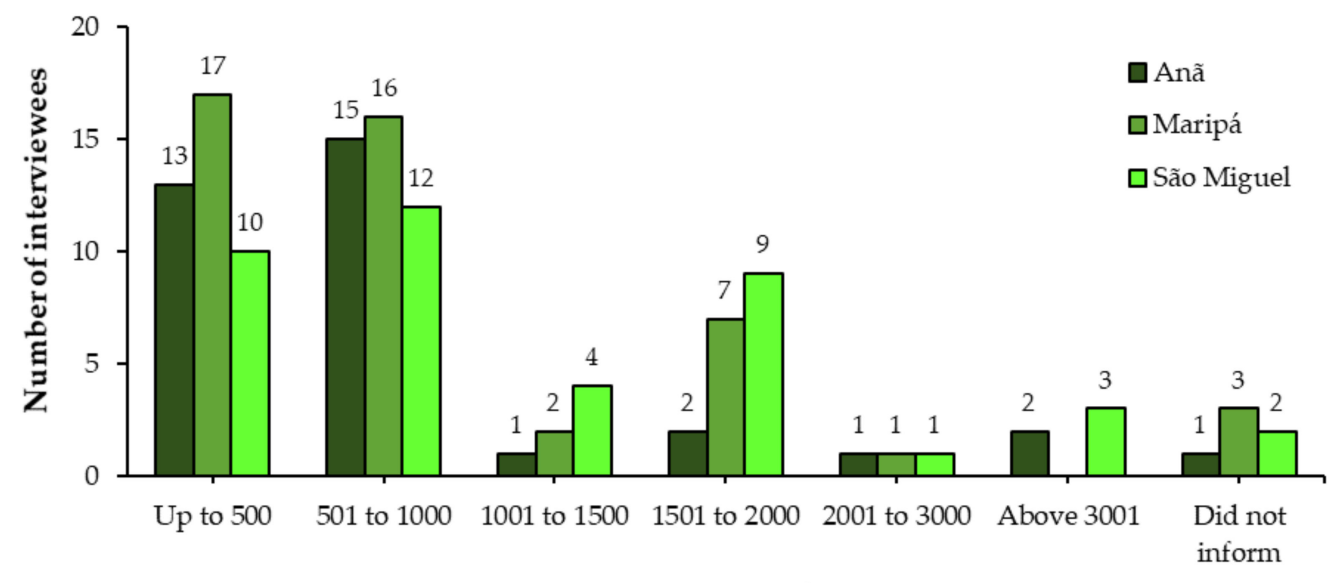

Family income (R\$)

Figure 3. Monthly family income (in Brazilian Real-R\$) of residents with tourism experience in three RESEX Tapajós-Arapiuns communities, Pará, Brazilian Amazonia; $1.00 €=6.55$ R $\$$, in 7 January 2021.

Most families (56\%) had their income supplemented by public social assistance policies, mainly through the Bolsa Família, a conditional cash transfer program (Figure 4). This situation also occurred among the communities of Marapanim, state of Pará, where the Bolsa Família program benefited $46.4 \%$ of the survey's informants [57] and also in the Tapajós National Forest, where this aid contributed to the maintenance of the families of that Conservation Unit [66]. This federal government program contributed to the fight against poverty and inequality in Brazil. It was created in October 2003, with the main pillars of income complement, access to rights, and articulation with other actions, to stimulate families' development, helping them overcome the situation of vulnerability and poverty [67]. In the Amazon region, assistance programs are the most important source of family income, together with the benefit of retirement, both at the federal and state levels [68].

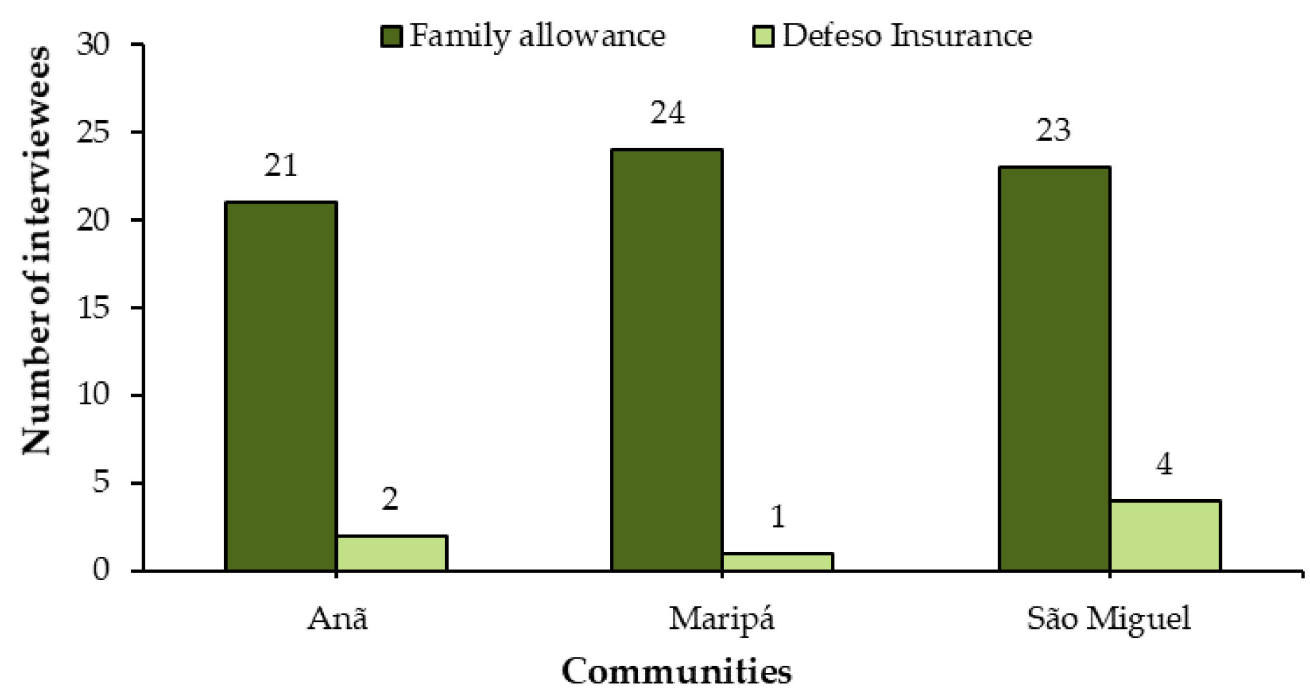

Figure 4. Receipt of government aid by families of extractivists with tourism experience from three RESEX Tapajós-Arapiuns communities, Pará, Brazilian Amazonia. 


\section{Community Infrastructure}

The media most cited by respondents were radio $(76 \%)$, television $(70 \%)$, and cell phones $(77 \%)$. The majority of the population does not have access to the internet in their homes. In this respect, the most privileged community is Maripá due to its proximity to the Alter do Chão district. Public telephones and community radios are installed in the communities (Figure 5).

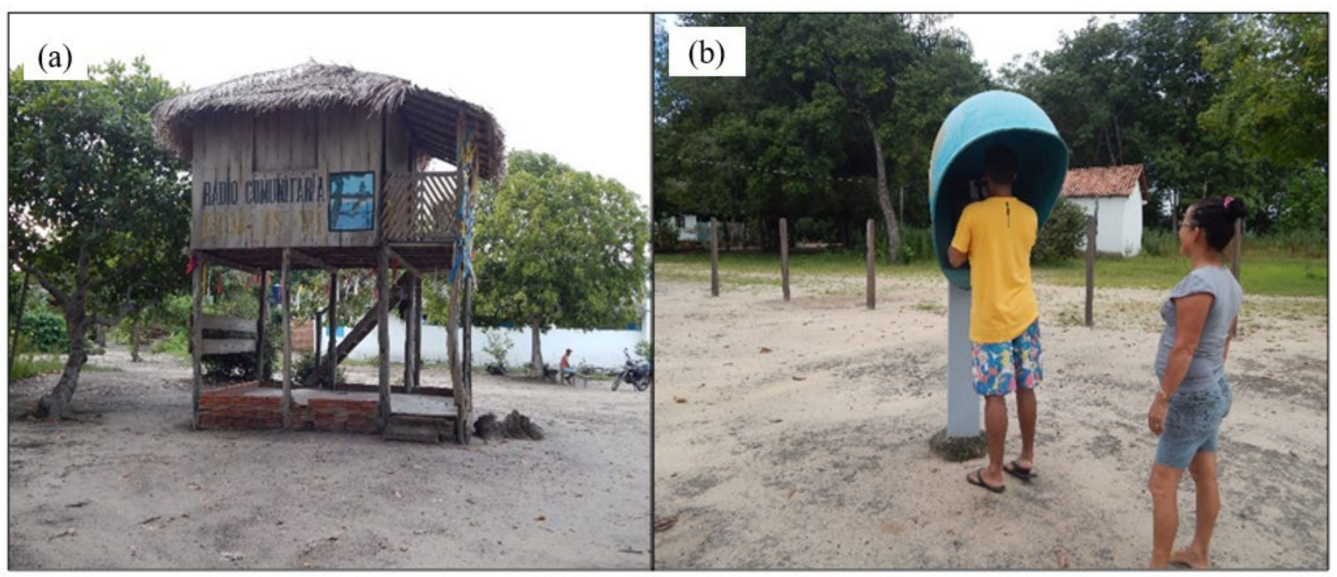

Figure 5. Aspects of two media in communities of RESEX Tapajós-Arapiuns, Pará, Brazilian Amazonia: (a) headquarters of the community radio in the community of Maripá; (b) public telephone in the community of Maripá.

In the Amazonia region, radio played a significant role in integrating capitals and distant locations in the interior, which in the first half of the 20th century were connected only by the river [69]. Printed newspapers were more concentrated in urban areas. The rural area remained very isolated. This situation only was broken by radio waves, which, being versatile, reached even the most distant communities on the riverside, in the mines, in the rubber plantations, on the farms, in the fields, and inside the canoes, boats, and ships [69].

The communities of Anã and São Miguel have a health post; in Maripá, a Community Health Agent is responsible for providing assistance and guidance in this area. The three communities have elementary schools, and only Anã and São Miguel have high schools (Figures 6 and 7). Health posts are installed in communities with more than 350 inhabitants and secondary education in communities with more than 150 people [70].

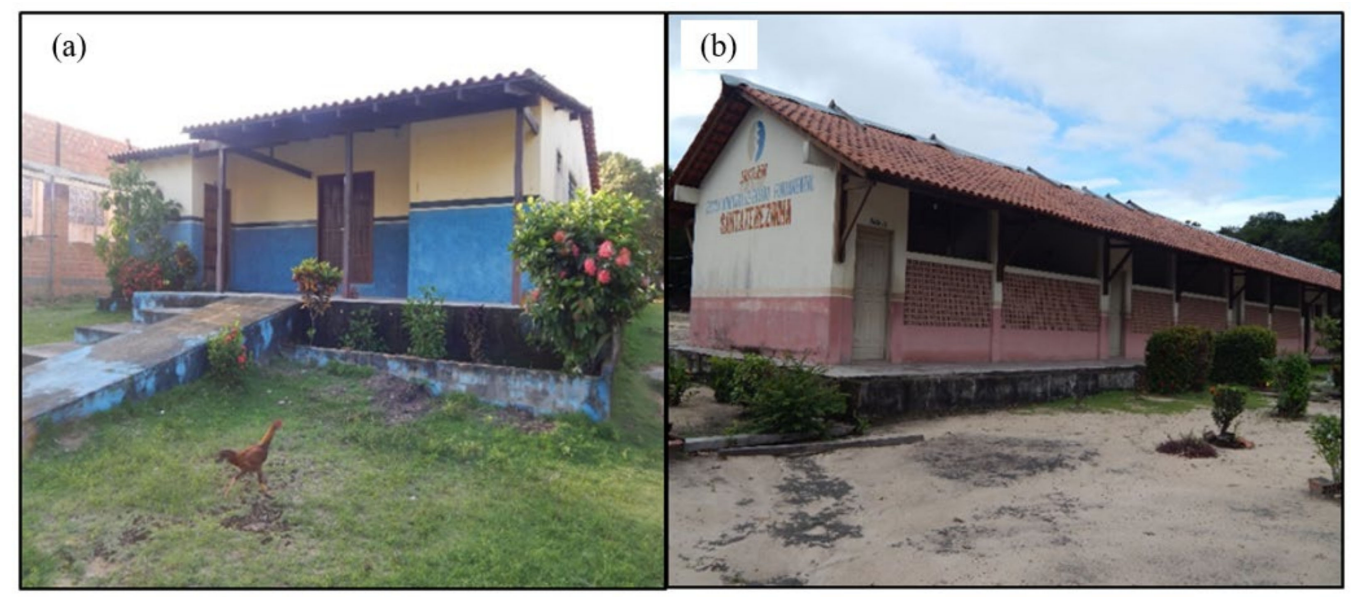

Figure 6. Infrastructure in two communities at RESEX Tapajós-Arapiuns, Pará, Brazilian Amazonia: (a) health post in the community of São Miguel; (b) elementary school in the community of Maripá. 


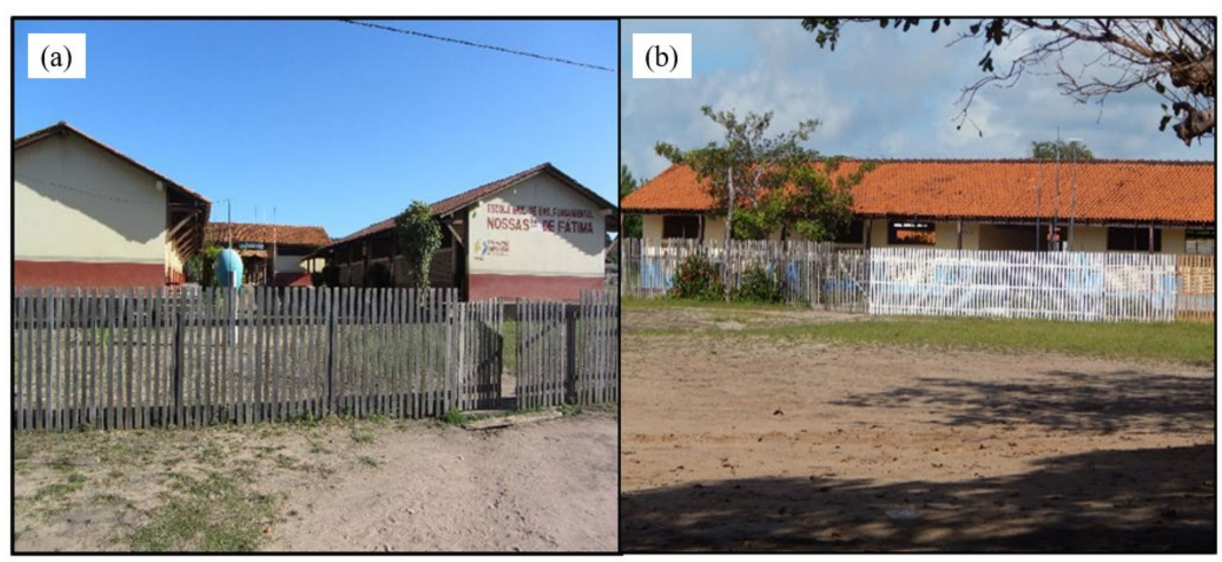

Figure 7. Infrastructure in two communities at RESEX Tapajós-Arapiuns, Pará, Brazilian Amazonia: (a) elementary and high school in the community of Anã; (b) elementary and high school in the community of São Miguel.

The students of Maripá continue their studies in Anã, traveling by land in transportation provided by the City Hall of Santarém, and problems with transportation have often been reported due to lack of maintenance, making it impossible for students to transfer. School meals are provided only for elementary school. The lack of food in schools is one of the causes of dropout in Santos [71]. Souza [72] shows that the school must be present in the riverside student's day-to-day life, seeking to value the local knowledge associated with formal knowledge. For this, it is necessary to make changes, concerning the official curriculum, so that learning is not an obligation or duty to fulfill, but as a possibility for new opportunities.

Another study showed the delimitation of services in the communities of Baixo Tapajós, causing the population to move to other communities and/or cities to have access to essential services, such as health and education [51]. The RESEX Tapajós-Arapiuns Management Plan informs that health posts are mostly located in the communities on the Tapajós river bank. Not all communities have schools, and energy is not offered $24 \mathrm{~h}$ because of the high maintenance costs of generator sets [31,32].

All communities have the water supply through microsystems (powered by electricity from an electric generator) (Figure 8a). Still, in São Miguel's case, some furthest from the center of the community are not benefited by this service, so the residents collect water directly from the river. Of the interviewees, $64 \%$ have a septic tank and receive energy from the community generator. Only in Maripá was an alternative form of energy identified: solar panels donated by an NGO to the community (Figure 8b). As for solid waste disposal, $74 \%$ of the informants performed burning (Table 3 ).

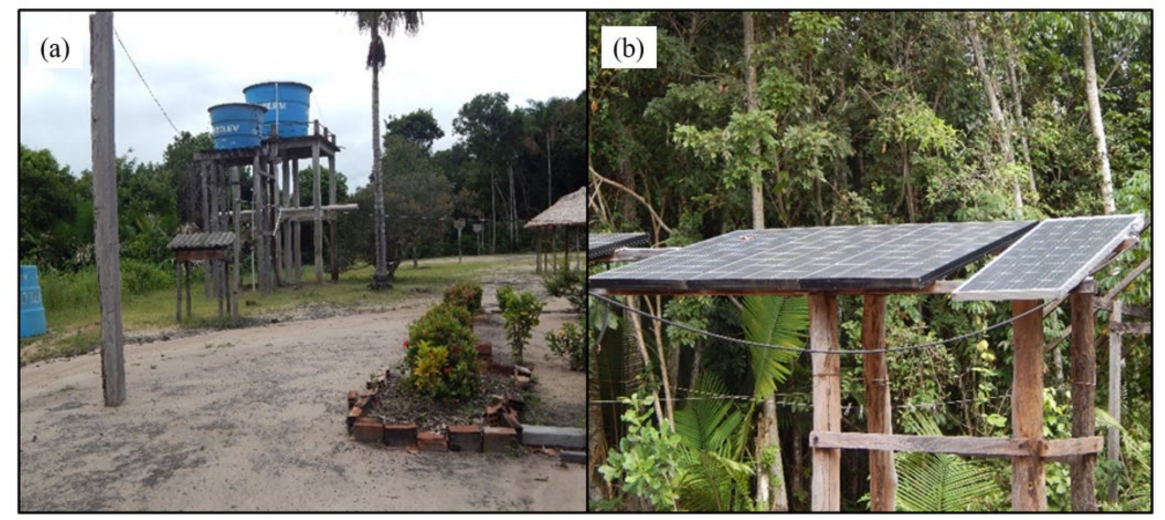

Figure 8. Infrastructure in two communities at RESEX Tapajós-Arapiuns, Pará, Brazilian Amazonia: (a) microsystem in the community of São Miguel; (b) solar panel in the community of Maripá. 
Table 3. Absolute number $(\mathrm{N})$ and percentage (\%) of responses from residents of three communities at RESEX Tapajós-Arapiuns, Pará, Brazilian Amazonia, about community infrastructure. N. = absolute number.

\begin{tabular}{lcc}
\hline Community Infrastructure & $\mathbf{N}$. & $\%$ \\
\hline Water supply & & \\
\hline Microsystem & 114 & $73 \%$ \\
River & 122 & $100 \%$ \\
Total & & \\
\hline Solid waste & 22 & $18 \%$ \\
\hline Dumping ground & 90 & $74 \%$ \\
Burnt & 10 & $8 \%$ \\
Buried & 122 & $100 \%$ \\
Total & & $5 \%$ \\
\hline Electric Energy & 6 & $64 \%$ \\
\hline Own generator & 78 & $20 \%$ \\
Community generator & 24 & $11 \%$ \\
Solar plate & 14 & $100 \%$ \\
No energy & 122 & \\
Total & & $64 \%$ \\
\hline Sewerage & 78 & $20 \%$ \\
\hline Septic tank & 24 & $16 \%$ \\
Black fossa & 20 & $100 \%$ \\
Clear sky & 122 & \\
\hline Total & & \\
\hline
\end{tabular}

The Trat Brazil Institute (Instituto Trata Brasil) since 2007 has published annually the ranking of sanitation of the 100 largest municipalities in Brazil in terms of population (with more than 300,000 inhabitants). In 2018, the municipality of Santarém ranked 97th, which is considered the fourth-worst in terms of sanitation [73,74]. The State Basic Sanitation Policy of Pará does not present considerations on basic sanitation for rural areas. However, the law addresses the universalization and execution of works and actions in rural areas; it does not indicate specific mechanisms for these areas' sanitation [75].

The lack of sanitation compromises the quality of life of the population. It can favor outbreaks of cholera and worms that are the most cited occurrences by municipalities, followed by endemics or dengue epidemics, in addition to zika and chikungunya. These diseases are transmitted by Aedes aegypti that reproduces in still water and the irregular water supply, which means that people have to build reservoirs that, when poorly covered, serve as breeding grounds for mosquitoes [73].

In cities where there is a lack of collection, sewage treatment, or lack of treated water, tourism does not develop, as the contamination of the environment compromises or even nullifies the region's tourist potential. Brazil would raise about 7 billion reais in tourism if basic sanitation services were universalized [73]. An example of this is countries like Chile, Cuba, and Argentina that have better performances in sanitation and present larger international flows of tourists.

In the global perception of the informants, $53.3 \%$ did not receive technical assistance in the communities. In Anã (51.4\%) and São Miguel (53.7\%), the informants observed the receipt of technical assistance from government agencies and NGOs; in Maripá, 67.4\% did not notice the presence of these institutions (Figure 9).

At the Alto Juruá RESEX, in Acre's state, the absence of technical assistance for extractivists created difficulties for their families in accessing social and credit programs [76]. Technical assistance services contribute significantly to the development of family farming and extractivism, provide communities with better living conditions, access to public policies aimed at the primary sector, and the opportunity to work with new technologies 
that facilitate the activity. On the other hand, the lack of assistance can compromise production in the short, medium, and long terms [76,77].

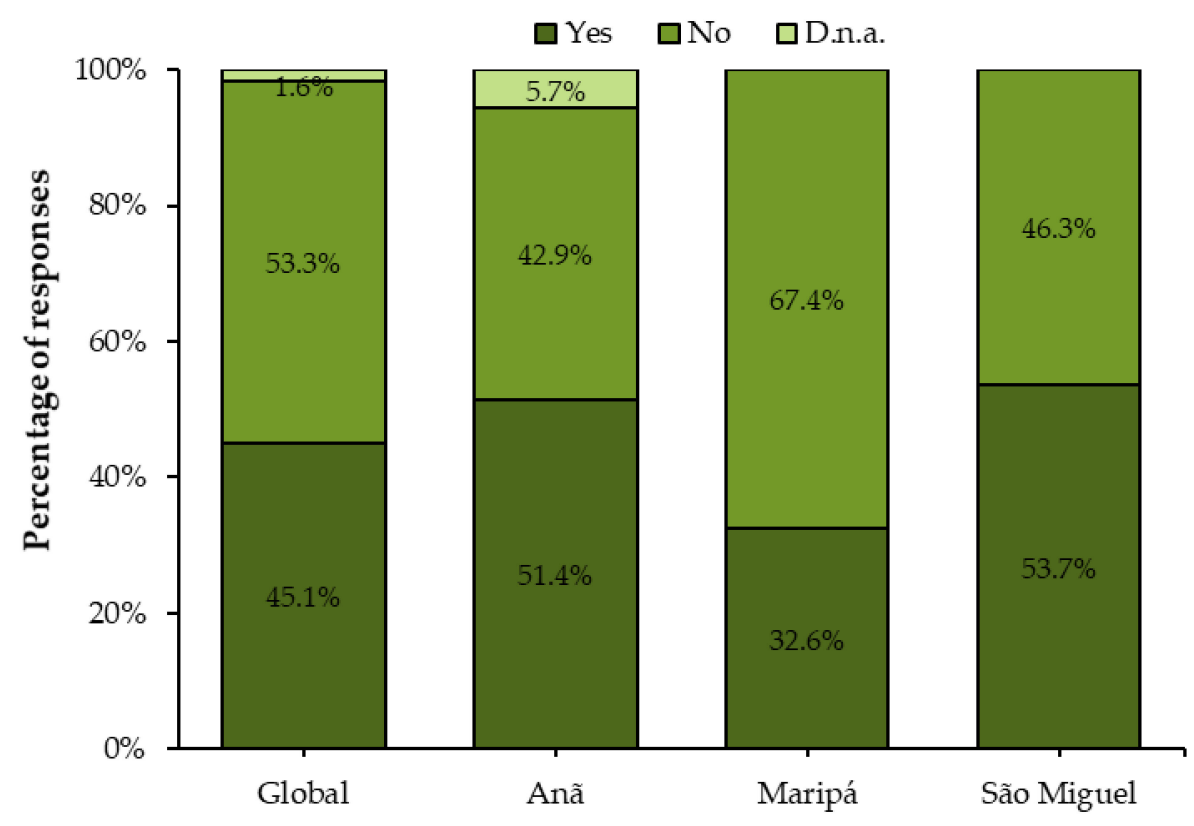

Receiving technical assistance

Figure 9. Global and community response percentage of residents of three RESEX Tapajós-Arapiuns communities, Pará, Brazilian Amazonia, about receiving technical assistance. D.n.a. = did not answer.

Of the total respondents, $63.9 \%$ knew the RESEX Tapajós-Arapiuns Management Plan. Management plans are instruments that describe the actions required for sustainable management and use in the Conservation Units' interior and areas. In Anã, 80\% responded to know the document, followed by Maripá (54.3\%) and São Miguel (61\%), but some reported knowing few subjects of its content (Figure 10).

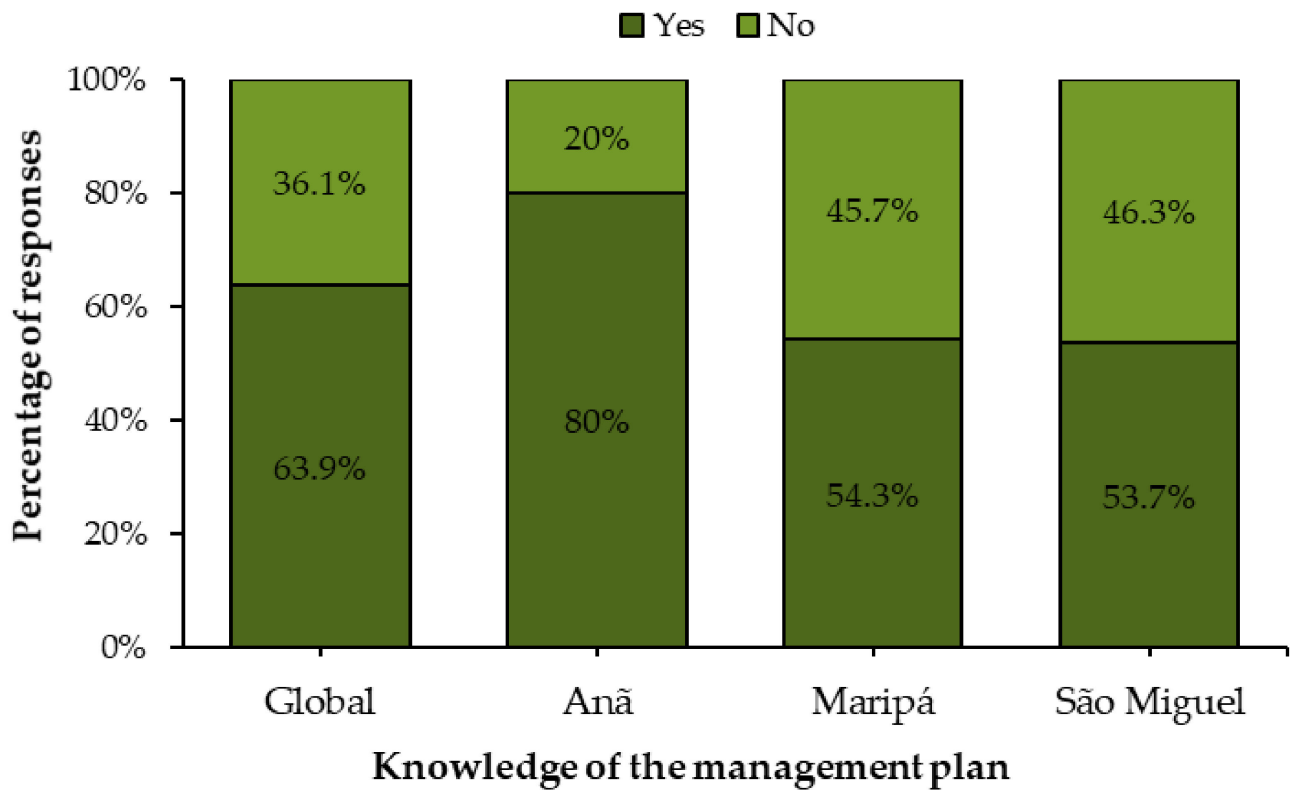

Figure 10. Global and community percentages of residents of three communities of RESEX TapajósArapiuns, Pará, Brazilian Amazonia, about the RESEX Tapajós-Arapiuns Management Plan knowledge. 
The Management Plans are critical technical documents prepared for the territorial organization and management of the Conservation Units. Normative Instruction (NI) No. 7/2017 established guidelines and procedures for the preparation and review of Management Plans for Federal UCs, as previously each Unit had its guidelines; it also serves as a reference for the elaboration of Management Plans in State and Municipal Conservation Units [78,79]. This NI has a chapter that clarifies how the specificities of Conservation Units will be with traditional populations, namely (i) recognizing, appreciating, and respecting the socio-environmental and the cultural diversity; (ii) ensuring the effective participation of traditional communities and social groups; (iii) valuing traditional knowledge and harmonizing sociocultural interests and nature conservation [79].

The Management Plans provide for information on the possibility of the correct development of tourism activities [80], as well as SNUC in its objectives, in article 4, item XII "to favor conditions and promote environmental education and interpretation, recreation in contact with nature and tourism ecological" [13].

\subsection{Perception of the Concept and Environmental Impacts of Alternative Tourism}

\subsubsection{Perception of the Concept of Alternative Tourism}

Of the total, $91.8 \%$ of the informants did not know how to explain the concept of alternative tourism. The informants who most knew how to answer were from the community of Maripá (13\%), followed by São Miguel (7.3\%) and Anã (2.9\%). Knowledge of the concept was viewed by expressions such as: "Adding tourists and bringing jobs to everyone" (Interviewee 22, Maripá); "Preservation tourism in small groups" (Interviewee 31, Maripá); "Which has several tourism options" (Interviewee 39 Maripá); "Various leisure alternatives" (Interviewee; 40 Maripá); "People who contribute to the community" (Interviewee 42, Maripá); "When tourists come, and the community offers traditional things, like food for them" (Interviewee 43, Maripá); "Knowing nature" (Interviewee 15, São Miguel); "Financial and environmental part" (Interviewee 22, São Miguel); "That doesn't come daily, ecotourism, publicizing the community" (Interviewee 35, São Miguel); and "It's Community Based Tourism" (Interviewee 35, Anã).

There were different definitions of alternative tourism attributed by the interviewees; however, some points were common among them, such as the "local contact of tourists with residents" and the "development of recreational activities in contact with nature". Perceptions were, in general, consistent with the development of alternative tourism, which is defined as development that is less commercialized and consistent with the natural, social, and community values of a host community, avoiding shared destinations and tourist packages, with a strong emphasis on contact with the environment [81-83]. On the other hand, mass tourism tends to be highly commercialized and offers minimal opportunities for contact and understanding between hosts and tourists [82]. Alternative tourism is based on the tripod of ecological, economic, and sociocultural sustainability of the localities. It respects the differences, the identity, the authenticity of the host communities, conservation, and environmental preservation [84]. Alternative tourism presupposes that the organizers or recipients are aware of a destination's social, cultural, and environmental values. In turn, tourists interact with community members participating in recreational activities in contact with nature and local cultural expressions [85]. This type of tourism comprises activities and characteristics of cultural tourism, ecotourism, adventure tourism, rural tourism, and community tourism with its variants.

A recent study carried out in the community of Anã verified that the village's tourism is not community-based, since the community members do not have autonomy in the management of the tourist activity in their territory [86]. To be considered communitybased tourism, the activity must fulfil criteria such as having the support and participation of the local population, maximum economic benefits absorbed by the local people, and protection of cultural identity and the environment [87]. The opposite happens at Mamirauá Sustainable Development Reserve (in the Brazilian Amazonia). In this case, there is a plan. 
The plan predicts a complete transfer of the Pousada Uacari management to the community members by 2022, and the training has taken place since 2013 [88].

\subsubsection{General Description of the Perception of the Character of Environmental Impacts}

Income $(53 \%)$, community organization $(7 \%)$, and knowledge $(5 \%)$ were the most frequent expressions used by RESEX Tapajós-Arapiuns residents to demonstrate what tourism brings with positive local impacts (Figure 11).

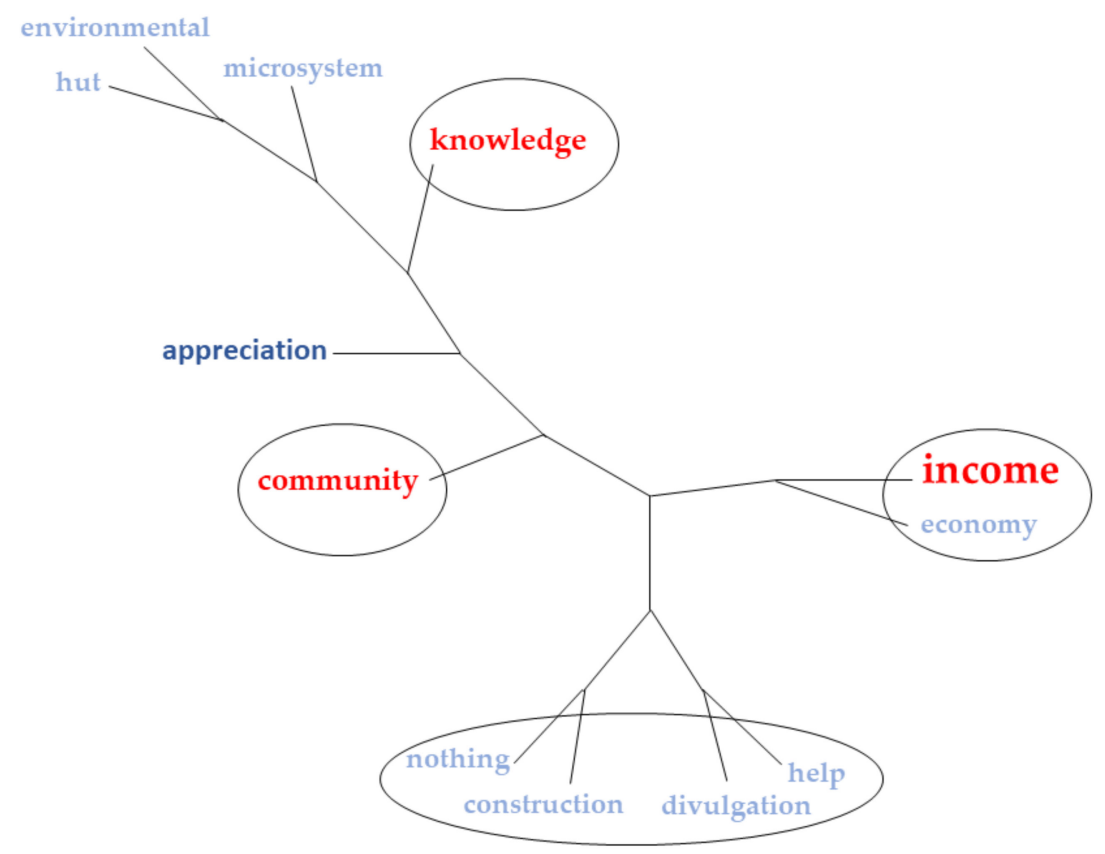

Figure 11. Similarity analysis of the 12 most frequent expressions used by extractivists to demonstrate the positive impacts of tourism for RESEX Tapajós-Arapiuns communities, Pará, Brazilian Amazonia. The size of a word is proportional to the frequency of its use.

The economic impacts of tourism are often seen in the short term; income is seen as the first benefit to tourism-receiving areas [89]. Tourists spend a considerable amount of money on protected areas and on the attractions offered, such as the costs of entering the area, lodging, hiring guides for walks or buying food, drinks, and handicrafts [19]. This was verified in Ubatuba-SP, where $60 \%$ of the interviewees perceived more positive than negative impacts [90] and the Centro Integralmente Planeado Loreto, in Baja California Sul, Mexico, where there was a positive perception (64.6\% of respondents), where the local economy was favored by tourism [91]. Social and cultural impacts take a longer time to occur. As they are qualitative changes, they are subtle and more difficult to measure [89], so the other characteristic pointed out by the community members was the knowledge acquired through tourism. It is a form of cultural exchange, one of the positive social impacts described by the literature, which helps preserve the localities' environment and culture $[89,92,93]$.

For $87.7 \%$ of respondents, there were no problems (negative impacts) caused by tourists in the RESEX Tapajós-Arapiuns, and only $5.7 \%$ observed negative impacts such as pollution in rivers and conflicts with community and with tourists (Figure 12). However, when asked about the environmental impact, $78 \%$ of the residents answered they did not know. At the Resex Tapajós-Arapiuns, visitors have contact with the place and with different ways of life for the population, for selling handicrafts, trails and canoe trips through forests and streams [31], and to enjoy the beaches at the time of the Amazonian summer.

A similar result was registered at RESEX Ponta do Corumbau, state of Bahia. The residents of the communities surveyed, Corumbau and Cumuruxatiba, reported not realizing 
that tourism caused negative impacts on their communities [94], which was also found in the research carried out in Ilhéus, state of Bahia, in which the informants did not perceive the occurrence of negative impacts [22].

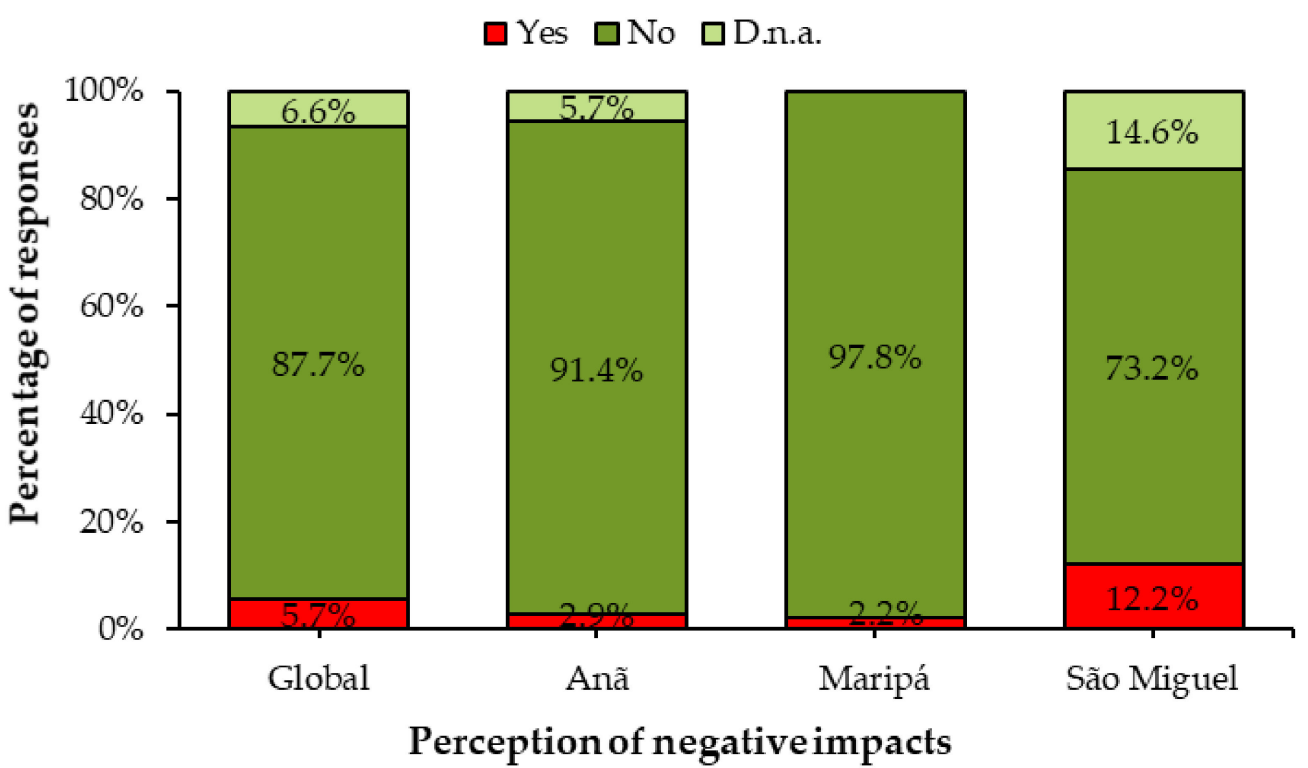

Figure 12. Global and community perceptions of extractivists about negative impacts caused by tourism in three RESEX Tapajós-Arapiuns communities, Pará, Brazilian Amazonia. D.n.a. = did not answer.

Conserved ecosystems can be important to the economy, especially for tourism, which draws in numerous tourists yearly who spend money on shopping and services, being an economic stimulus to the region [95]. The environmental impact is "the alteration of the environmental quality that results from the modification of natural or social processes caused by human action", which can be of a negative or positive character. The residue left in the river or beaches of the communities can result in negative impacts, such as the death of fish, the attraction of animals such as vultures (Coragyps atratus), or visual pollution [96].

A hypothesis that can justify this perception is the lack of knowledge of what environmental impact is. According to Gursoy [97], the higher the level of residents' ecological values, the lower the benefits of tourism development perceived. In the case of this study at RESEX Tapajós-Arapiuns, the opposite was shown; the level of ecological appreciation was lower, so most did not observe the negative impacts. Other factors can also influence whether the impact will be positive or negative in a specific location, such as the strength and coherence of local society and culture, the type of tourism, the degree of social and economic development of the local population concerning tourists, and support from the public sector to manage tourism to minimize its environmental costs [98].

This is contrary to what is observed in mass tourism, where residents perceive negative environmental impacts. In a study conducted by Oliveira et al. [99], held at Ponta de Pedras beach, municipality of Santarém (Pará), various types of solid waste were found on the beaches and were not disposed properly, in addition to the lack of sanitary sewage. The study by Alves and Granado [100], on the beaches of the municipal bathhouse of Rosano, state of São Paulo, recorded the banks' erosion, extraction of vegetation cover, and the presence of solid waste along the beaches.

\subsubsection{Perception of the Economic Impacts of Tourism}

Of the interviewees, $82 \%$ were aware that a visitation fee is charged to tourists to access the RESEX Tapajós-Arapiuns; this fee contributes to the community for the maintenance of local expenses, and accountability is carried out in a monthly community meeting by the person responsible for the collection (Table 4). In RDS Mamirauá, state of Amazonas, 
tourists are also charged a fee called "Socioenvironmental Support Fee" included in the Pousada Uacari tariff. The amount is used to finance community projects and the area's environmental surveillance [101].

Table 4. Absolute number $(\mathrm{N})$ and percentage (\%) of responses from residents of three communities at RESEX Tapajós-Arapiuns, Pará, Brazilian Amazonia, regarding the perception of changes in the economy caused by alternative tourism. N. = absolute number; D.n.a. = did not answer.

\begin{tabular}{|c|c|c|c|c|c|c|c|c|}
\hline \multirow{3}{*}{ Questions } & \multicolumn{6}{|c|}{ RESEX Communities } & \multirow{2}{*}{\multicolumn{2}{|c|}{ Total }} \\
\hline & \multicolumn{2}{|c|}{ Anã } & \multicolumn{2}{|c|}{ Maripá } & \multicolumn{2}{|c|}{ São Miguel } & & \\
\hline & $\mathbf{N}$. & $\%$ & N. & $\%$ & N. & $\%$ & N. & $\%$ \\
\hline \multicolumn{9}{|c|}{ Knowledge of charging fees to tourists? } \\
\hline Yes & 30 & 85.7 & 43 & 93.5 & 27 & 65.9 & 100 & 82 \\
\hline No & 5 & 14.3 & 3 & 6.5 & 14 & 34.1 & 22 & 18 \\
\hline Total & 35 & 100 & 46 & 100 & 41 & 100 & 122 & 100 \\
\hline \multicolumn{9}{|c|}{ Is tourism the main activity that brings income to the community? } \\
\hline Yes & 10 & 28.6 & 4 & 8.7 & 16 & 39.0 & 30 & 24.6 \\
\hline No & 24 & 68.6 & 42 & 91.3 & 23 & 56.1 & 89 & 73 \\
\hline D.n.a. & 1 & 2.9 & - & - & 2 & 4.9 & 3 & 2.5 \\
\hline Total & 35 & 100 & 46 & 100 & 41 & 100 & 122 & 100 \\
\hline \multicolumn{9}{|c|}{ Has the number of people interested in working with tourism in the community grown? } \\
\hline Yes & 25 & 71.4 & 15 & 32.6 & 29 & 70.7 & 69 & 56.6 \\
\hline No & 6 & 17.1 & 29 & 63 & 7 & 17.1 & 42 & 34.4 \\
\hline D.n.a. & 4 & 11.4 & 2 & 4.3 & 5 & 12.2 & 11 & 9 \\
\hline Total & 35 & 100 & 46 & 100 & 41 & 100 & 122 & 100 \\
\hline \multicolumn{9}{|c|}{ Do traders increase product prices because of tourism? } \\
\hline Yes & - & - & 5 & 10.9 & 4 & 9.8 & 9 & 7.4 \\
\hline No & 28 & 80 & 30 & 65.2 & 19 & 46.3 & 77 & 63.1 \\
\hline D.n.a. & 7 & 20 & 11 & 23.9 & 18 & 43.9 & 36 & 29.5 \\
\hline Total & 35 & 100 & 46 & 100 & 41 & 100 & 122 & 100 \\
\hline
\end{tabular}

For $73 \%$ of the respondents, tourism was not the main economic activity contributing to household income (Table 4). As reported in Figure 2, the main economic activity was agriculture. Some extractivists interviewed said that they work with tourists' reception and take care of the visitors' meals and their accommodations at the inn, in hammocks/malocas or their own homes (Figure 13). Employment options in tourism can be simple, weakening the sector with low wages and low qualification requirements, offering few opportunities for the advancement and training of the local population, and the seasonality of tourism weakens the sector [102].

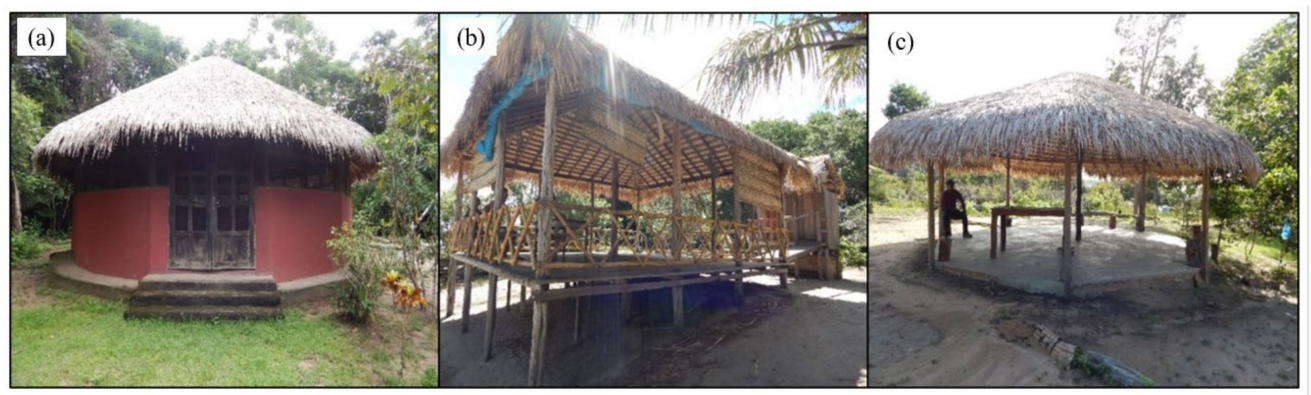

Figure 13. Accommodation for tourists in the RESEX Tapajós-Arapiuns communities, Pará, Brazilian Amazonia. (a) Anã, (b) Maripá, and (c) São Miguel. 
As for the growth in people's interest in working in tourism, $56.6 \%$ answered yes (Table 4). Non-agricultural activities play an important role in the composition of rural families' total income, which can be considered strategic activities for communities' socioeconomic growth [103]. In this sense, in the Tapajós National Forest, in a Conservation Unit close to the RESEX Tapajós-Arapiuns, residents understand that tourism is a productive activity and deserves special attention. They suggest creating and articulating a network of partners to offer courses in reception of tourists, English language, and first aid [66]. The economic benefits resulting from protecting tourism areas offer a potential compensation to the local population, who has to bear the majority of indirect costs resulting from land-use restrictions associated with the protection status of a particular area [104]. In the world, principally in less-developed countries, this potential tourism is rarely observed because poverty and social desperation leave the local community to benefit from tourism development, but with low participation of the host population in the development process, compromising tourism income [105]. At RESEX Tapajós-Arapiuns (our study area) this must be secondary to local communities, since none of the interviewees considered tourism their primary source of income.

Local commerce does not increase their goods' value because of tourist activities in the communities (Table 4). The tourist demand is concentrated in short periods, and sometimes tourists have a higher spending capacity than those who are not tourists. There is a tendency for goods and service prices to rise in the region visited. Thus, some of these goods that both tourists and locals consume increase for both [106]. This price increase has a positive impact on traders and people who work directly with tourism. Still, for a part of the community that does not work either directly or indirectly, it becomes a negative impact, as access to goods becomes more costly.

\subsubsection{Perception of Cultural impacts of Tourism}

For $64.8 \%$ of the interviewees, tourists are interested in knowing how the communities live, interacting with the locals (Table 5). In the informants' view (74.6\%), this relationship does not influence the change in local customs; on the contrary, they feel more valued and realize the importance of maintaining their traditions (Table 5 and Figure 14). For 68\% of the informants, there was no increase in tourist recreation options in the communities (Table 5).

Table 5. Absolute number $(\mathrm{N})$ and percentage (\%) of responses from residents of three communities at RESEX Tapajós-Arapiuns, Pará, Brazilian Amazonia, about cultural changes caused by alternative tourism at RESEX. N. = absolute number; D.n.a. = did not answer.

\begin{tabular}{|c|c|c|c|c|c|c|c|c|}
\hline \multirow{3}{*}{ Questions } & \multicolumn{6}{|c|}{ RESEX Communities } & \multirow{2}{*}{\multicolumn{2}{|c|}{ Total }} \\
\hline & \multirow{2}{*}{$\begin{array}{c}\text { Anã } \\
\text { N. }\end{array}$} & \multicolumn{3}{|c|}{ Maripá } & \multicolumn{2}{|c|}{ São Miguel } & & \\
\hline & & $\%$ & N. & $\%$ & N. & $\%$ & N. & $\%$ \\
\hline \multicolumn{9}{|c|}{ Is there interaction between tourists and locals? } \\
\hline Yes & 26 & 74.3 & 24 & 52.2 & 29 & 70.7 & 79 & 64.8 \\
\hline No & 8 & 22.9 & 15 & 32.6 & 10 & 24.4 & 33 & 27.0 \\
\hline D.n.a. & 1 & 2.9 & 7 & 15.2 & 2 & 4.9 & 10 & 8.2 \\
\hline Total & 35 & 100 & 46 & 100 & 41 & 100 & 122 & 100 \\
\hline \multicolumn{9}{|c|}{ Do residents experience changes in customs because of contact with tourists? } \\
\hline Yes & 7 & 20.0 & 5 & 10.9 & 15 & 36.6 & 27 & 22.1 \\
\hline No & 27 & 77.1 & 41 & 89.1 & 23 & 56.1 & 91 & 74.6 \\
\hline D.n.a. & 1 & 2.9 & - & - & 3 & 7.3 & 4 & 3.3 \\
\hline Total & 35 & 100 & 46 & 100 & 41 & 100 & 122 & 100 \\
\hline \multicolumn{9}{|c|}{ Does tourism bring more recreation options to the community? } \\
\hline Yes & 17 & 48.6 & 7 & 15.2 & 12 & 29.3 & 36 & 29.5 \\
\hline No & 17 & 48.6 & 39 & 84.8 & 27 & 65.9 & 83 & 68 \\
\hline D.n.a. & 1 & 2.9 & - & - & 2 & 4.9 & 3 & 2.5 \\
\hline Total & 35 & 100 & 46 & 100 & 41 & 100 & 122 & 100 \\
\hline
\end{tabular}




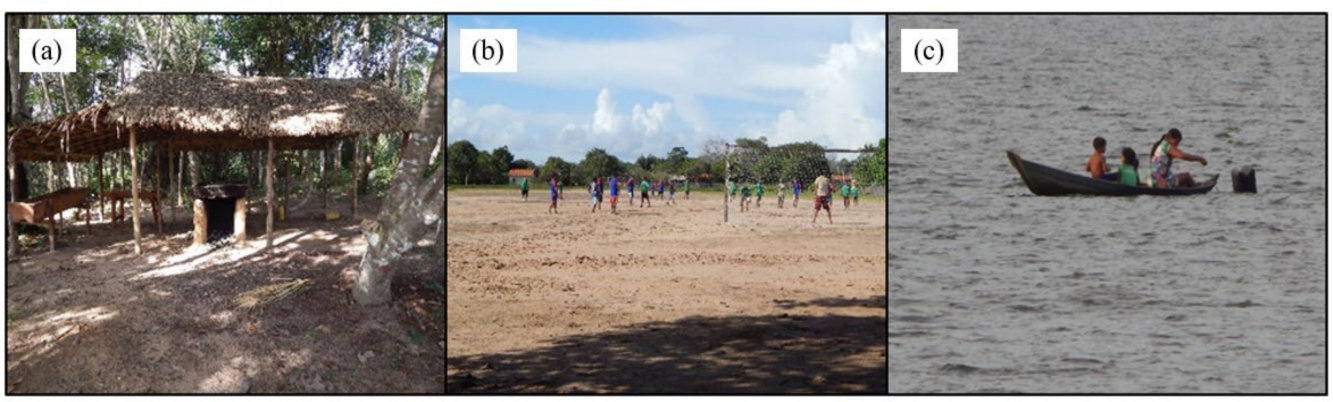

Figure 14. Cultural habits in RESEX Tapajós-Arapiuns communities, Pará, Brazilian Amazonia: (a) flour mill in São Miguel, (b) soccer game in São Miguel, and (c) fishing woman in Anã.

Hosts are more likely to borrow certain cultural elements than their tourists. As a community adapts to meet tourists' needs, it tends to become something more and more similar to the culture of visitors, a phenomenon called "acculturation" [107]. This fact is not perceived in the communities surveyed, and some attributed the change in habits related to the influence of television. Tourism is only one of the factors, among many, responsible for modifying the population's way of life, as cultural dependence, television, the internet, the press, commercial advertising, and globalization itself also contribute to a change in physical environments and social and cultural attractions of a tourist destination [108]. However, it is worth mentioning that tourism in protected areas helps communicate and interpret cultural inheritance values to tourists and residents of visited areas, thus building a new generation of responsible consumers $[109,110]$.

The cultural activities perceived by the residents of RESEX Tapajós-Arapiuns are opposed to those found by Oliveira [22], who mentions that $77 \%$ of the residents perceive the interference of tourism in the offer of recreation in the city of Ilhéus (BA). Tourist attractions are responsible for choosing the tourist for a given destination that attracts the tourist flow. Cultural events and activities, in which tourists can participate, differentiate the destination from the others because its attractions have their own identity. These events and activities can be, for example, performing arts, regional music, handicrafts, folklore, typical gastronomy, literature, traditions, uses and customs, and participation in the daily lives of communities, such as planting or harvesting products, animal care, and the preparation of meals [111].

\subsubsection{Perception of the Social and Political Impacts of Tourism}

Almost all respondents did not identify the occurrence of violence (94.3\%); the reports identified were related to "discussions about excessive drinking with residents and/or among tourists" (Interviewees 7, 27, 70, 104) and "Discussion because of refusal to take the fee for the community" (Interviewees 113, 114) and sexual exploitation $(99.2 \%)$ related to tourism in the communities (Table 6). For $86.1 \%$ of respondents, the government did not invest in infrastructure improvements to encourage tourism (Table 6). Many respondents (66.4\%) did not perceive the government or NGOs' presence to maintain conserved environments, and $51.6 \%$ participated in training focused on tourism (Table 6).

The existence of tourism policies is essential to monitor this sector's activities and increase their benefits [93]. However, its existence does not mean that all tourism problems in a locality will be solved, but they can be structurally identified and mitigated to serve the community's interests and provide benefits through an articulated decision-making process [112]. Agreements between stakeholders, including the locals, can be beneficial to both, but will not occur automatically, principally if the current political context in some countries is a risk to public protected areas [113]. Furthermore, the absence of public policies can intensify communities' negative impacts by the unsustainable use of natural resources.

For communities to realize socioeconomic benefits, the community must be accessible and have adequate infrastructure to sustain the desired level of tourism and the local 
population's growth. Drinking water, sewage systems, and waste management are fundamental, together with the maintenance and modernization of roads, the promotion of sustainable means of transport to and from the protected area, and the construction of communication networks, such as landlines, cell phone towers, and internet access [114]. This intervention would facilitate the necessary connections between tourists, the local community, the protected area, and the outside world.

Table 6. Absolute number $(\mathbf{N})$ and percentage (\%) of responses from residents of three communities at RESEX Tapajós-Arapiuns, Pará, Brazilian Amazonia, about social and political changes caused by alternative tourism at RESEX. N. = absolute number; D.n.a. = did not answer.

\begin{tabular}{|c|c|c|c|c|c|c|c|c|}
\hline \multirow{3}{*}{ Questions } & \multicolumn{6}{|c|}{ RESEX Communities } & \multirow{2}{*}{\multicolumn{2}{|c|}{ Total }} \\
\hline & \multicolumn{2}{|c|}{ Anã } & \multicolumn{2}{|c|}{ Maripá } & \multicolumn{2}{|c|}{ São Miguel } & & \\
\hline & N. & $\%$ & N. & $\%$ & N. & $\%$ & N. & $\%$ \\
\hline \multicolumn{9}{|c|}{ Do you notice the existence of violence in the community because of tourism? } \\
\hline Yes & 2 & 5.7 & 1 & 2.2 & 3 & 7.3 & 6 & 4.9 \\
\hline No & 33 & 94.3 & 45 & 97.8 & 37 & 90.2 & 115 & 94.3 \\
\hline D.n.a. & - & - & - & - & 1 & 2.4 & 1 & 0.8 \\
\hline Total & 35 & 100 & 46 & 100 & 41 & 100 & 122 & 100 \\
\hline \multicolumn{9}{|c|}{ Do you see if there is sexual exploitation in the community because of tourism? } \\
\hline Yes & 35 & 100 & 46 & 100 & 40 & 98 & 121 & 99.2 \\
\hline No & - & - & - & - & 1 & 2 & 1 & 0.8 \\
\hline Total & 35 & 100 & 46 & 100 & 41 & 100 & 122 & 100 \\
\hline \multicolumn{9}{|c|}{ Has the government started to invest more in the community because of tourism? } \\
\hline Yes & 3 & 8.6 & 2 & 4.3 & 4 & 9.8 & 9 & 7.4 \\
\hline No & 29 & 82.9 & 42 & 91.3 & 34 & 82.9 & 105 & 86.1 \\
\hline D.n.a. & 3 & 8.6 & 2 & 4.3 & 3 & 7.3 & 8 & 6.6 \\
\hline Total & 35 & 100 & 46 & 100 & 41 & 100 & 122 & 100 \\
\hline \multicolumn{9}{|c|}{$\begin{array}{l}\text { Do you perceive government or NGO interventions so that the community's environment } \\
\text { remains conserved? }\end{array}$} \\
\hline Yes & 21 & 60 & 10 & 21.7 & 7 & 17.1 & 38 & 31.1 \\
\hline No & 13 & 37.1 & 35 & 76.1 & 33 & 80.5 & 81 & 66.4 \\
\hline D.n.a. & 1 & 2.9 & 1 & 2.2 & 1 & 2.4 & 3 & 2.5 \\
\hline Total & 35 & 100 & 46 & 100 & 41 & 100 & 122 & 100 \\
\hline \multicolumn{9}{|c|}{ Has there been any training offered by the government or NGOs for tourism? } \\
\hline Yes & 24 & 68.6 & 21 & 45.7 & 18 & 43.9 & 63 & 51.6 \\
\hline No & 7 & 20.0 & 23 & 50.0 & 19 & 46.3 & 49 & 40.2 \\
\hline D.n.a. & 4 & 11.4 & 2 & 4.3 & 4 & 9.8 & 10 & 8.2 \\
\hline Total & 35 & 100 & 46 & 100 & 41 & 100 & 122 & 100 \\
\hline
\end{tabular}

Possibly, most of the local population does not know the tourism policies, which would prevent some families from training and participating in tourism. The local government should identify new stakeholders interested in participating in tourism, listen to their suggestions, and understand their needs, having a horizontal decision-making style based on multiple stakeholders [115].

\subsubsection{Perception of Tourism Impacts on Natural Environments}

Of the interviewees, $89.3 \%$ did not verify that tourists pollute the environments with solid waste. For $85.2 \%$ the vessels that transport the visitors also did not leave residues on the beaches or rivers, and visual and noise pollution was not perceived (Table 7). The results are in line with other studies. The accumulation of garbage and visual and noise pollution caused by tourist activities was evidenced [116-119]. 
Table 7. Percentage (\%) of responses from residents of three communities at RESEX Tapajós-Arapiuns, Pará, Brazilian Amazonia, about changes in natural environments caused by alternative tourism at RESEX. N.= absolute number; D.n.a. = did not answer.

\begin{tabular}{|c|c|c|c|c|c|c|c|c|}
\hline \multirow{3}{*}{ Questions } & \multicolumn{6}{|c|}{ RESEX Communities } & \multirow{2}{*}{\multicolumn{2}{|c|}{ Total }} \\
\hline & \multicolumn{2}{|c|}{ Anã } & \multicolumn{2}{|c|}{ Maripá } & \multicolumn{2}{|c|}{ São Miguel } & & \\
\hline & N. & $\%$ & N. & $\%$ & N. & $\%$ & N. & $\%$ \\
\hline \multicolumn{9}{|c|}{ Do tourists leave waste in rivers or trails? } \\
\hline Yes & 1 & 2.9 & 1 & 2.2 & 2 & 4.9 & 4 & 3.3 \\
\hline No & 32 & 91.4 & 42 & 91.3 & 35 & 85.4 & 109 & 89.3 \\
\hline D.n.a. & 2 & 5.7 & 3 & 6.5 & 4 & 9.8 & 9 & 7.4 \\
\hline Total & 35 & 100 & 46 & 100 & 41 & 100 & 122 & 100 \\
\hline \multicolumn{9}{|c|}{ Do you notice if the tourist boats leave some kind of residue on the beaches or river? } \\
\hline Yes & - & - & 1 & 2.2 & 9 & 22.0 & 10 & 8.2 \\
\hline No & 33 & 94.3 & 43 & 93.5 & 28 & 68.3 & 104 & 85.2 \\
\hline D.n.a. & 2 & 5.7 & 2 & 4.3 & 4 & 9.8 & 8 & 6.6 \\
\hline Total & 35 & 100 & 46 & 100 & 41 & 100 & 122 & 100 \\
\hline \multicolumn{9}{|c|}{ Do tourists cause visual pollution in the environments visited? } \\
\hline Yes & 3 & 8.6 & 2 & 4.3 & 1 & 2.4 & 6 & 4.9 \\
\hline No & 32 & 91.4 & 44 & 95.7 & 36 & 87.8 & 112 & 91.8 \\
\hline D.n.a. & - & - & - & - & 4 & 9.8 & 4 & 3 \\
\hline Total & 35 & 100 & 46 & 100 & 41 & 100 & 122 & 100 \\
\hline \multicolumn{9}{|c|}{ Do tourists cause noise pollution in environments? } \\
\hline No & 35 & 100 & 44 & 95.7 & 37 & 90.2 & 116 & 95.1 \\
\hline D.n.a. & - & - & 2 & 4.3 & 4 & 9.8 & 6 & 4.9 \\
\hline Total & 35 & 100 & 46 & 100 & 41 & 100 & 122 & 100 \\
\hline \multicolumn{9}{|c|}{ Do you notice any change in the landscape because of tourism in the community? } \\
\hline Yes & 6 & 17.1 & 5 & 10.9 & 7 & 17.1 & 18 & 14.8 \\
\hline No & 27 & 77.1 & 40 & 87 & 30 & 73.2 & 97 & 79.5 \\
\hline D.n.a. & 2 & 5.7 & 1 & 2.2 & 4 & 9.8 & 7 & 5.7 \\
\hline Total & 35 & 100 & 46 & 100 & 41 & 100 & 122 & 100 \\
\hline \multicolumn{9}{|c|}{ Do you notice if tourists remove any animals or plants from the community? } \\
\hline Yes & - & - & 2 & 4.3 & 2 & 4.9 & 4 & 3.3 \\
\hline No & 33 & 94.3 & 41 & 89.1 & 32 & 78 & 106 & 86.9 \\
\hline D.n.a. & 2 & 5.7 & 3 & 6.5 & 7 & 17.1 & 12 & 9.8 \\
\hline Total & 35 & 100 & 46 & 100 & 41 & 100 & 122 & 100 \\
\hline
\end{tabular}

During the Amazonian summer, there is the formation of beaches on the banks of the Tapajós and Arapiuns rivers in the studied RESEX. This reality is a major attraction for tourists, even if there are no bars and/or restaurants installed (Figure 15) to serve tourists. These environments receive small groups of tourists accompanied by community members at all times, which makes negative environmental impacts difficult. Access to the reserve is only by river, which makes the trip more distant. It is believed that this difficulty makes it impossible to make more disordered visits to the beaches and the communities.

In the surveyed communities, $79.5 \%$ of respondents did not perceive changes in the landscape caused by tourism (Table 7), and those who perceived changes reported "more cleanliness in the community" (Interviewees 14, 15, 16, 17, 33, 61, 76, 90, 91, 107, 113), "polluted lake" (Interviewee 39), "trail opening" (Interviewee 5, 103), "greater environmental awareness" (Interviewee 79), "the beaches are more polluted and the water more cloudy" (Interviewee 68), "signpost implantation" (Interviewee 108), and "access to streams" (Interviewee 114). 


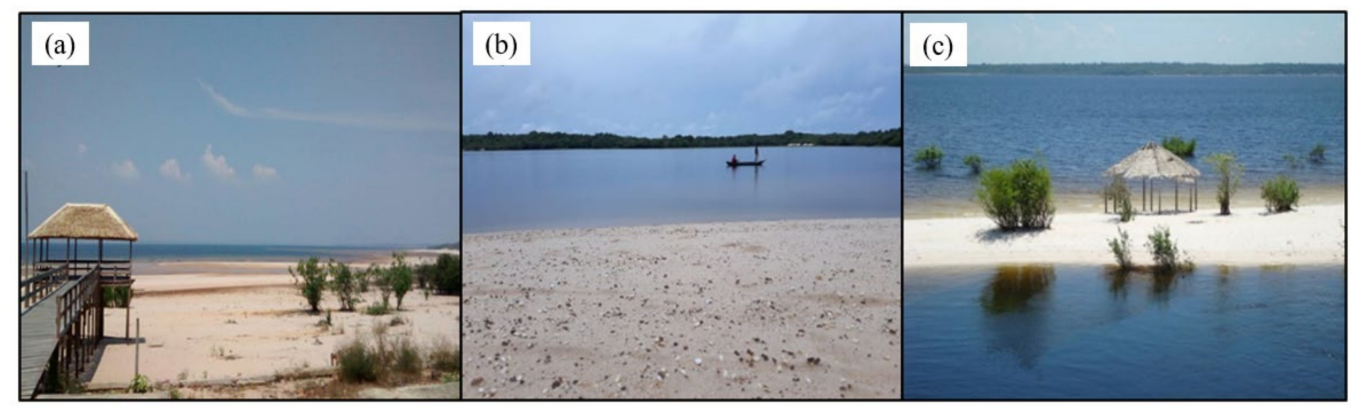

Figure 15. Beaches that form in summer in RESEX communities Tapajós-Arapiuns, Pará, Brazilian Amazonia. (a) Anã; (b) Maripá, and (c) São Miguel. Source: (a) INPE (2012); (b) Larissa Maia (2018); (c) https:/ / mapio.net/pic/p-12999580/ (accessed on 24 April 2019).

The more fragile the landscape, the easier it will be to de-characterize through actions in the area. In other words, the more attractive and visible the landscape is, the greater its degree of fragility; after all, it will be prone to attract more activities and visitors [120].

Regarding removing animals and/or plants from the forest, $86.9 \%$ of the interviewees affirmed that tourists did not do it (Table 7). The community members know that such an activity is not allowed and can configure biopiracy. This practice is registered by Cordeiro and Körössy [121] in the Fernando de Noronha National Marine Park, state of Pernambuco (Brazil), where the removal of invertebrate species was observed, which have even been found for sale on conquiliology websites. Thus, if tourist activities are not practiced with adequate guidance and with adequate facilities to limit human disturbance, they can in the short-term result in negative consequences, as observed by Guillemain et al. [9] when assessing the disturbance of ecotourism to wildfowl in protected areas in Camargue, Southern France.

The ecotourist generally cares about the uniqueness and authenticity of the experience, with the state of conservation of the environment with the desire to contribute to its preservation [122]. They usually visit remote places with little or no tourist infrastructure and are concerned with minimally impacting the environment and adopting preventive measures throughout their trip [123].

The environmental attitudes promote environmentally friendly behavior, and tourists can (a) be proactive with the environment and their interest in its protection, exerting a crucial role in creating balance in their life; (b) to dislike certain types of conservation work by tourism [124]. In this sense, activities of environmental education exert important roles to tourism in protected areas.

The environmental behavior of residents must go in the direction of conservation practices. In this sense, they must become the community's management objective, as activities such as cleaning efforts and environmental education projects are carried out by schools [112]. The environmental education process must be permanent. Individuals and the community have to become aware of their environment and acquire knowledge, skills, experiences, values, and determination capable of acting, individually or collectively, searching for solutions to environmental problems, present and future [125].

\subsubsection{Perception of Positive and Negative Environmental Impacts of Tourism} on Communities

The association of the two axes of the PCA represented 53.13\% of the variation in responses. Only the first axis was analyzed since the second axis did not present an observed value greater than that estimated by the Broken-stick procedure. The first axis explained $35.24 \%$ of the results. In this analysis, the responses were clearly separated by the impacts' character (positive and negative) (Figure 16). It is important to note here the answers that contributed most to the formation of the first axis were closely related to camps' construction. 


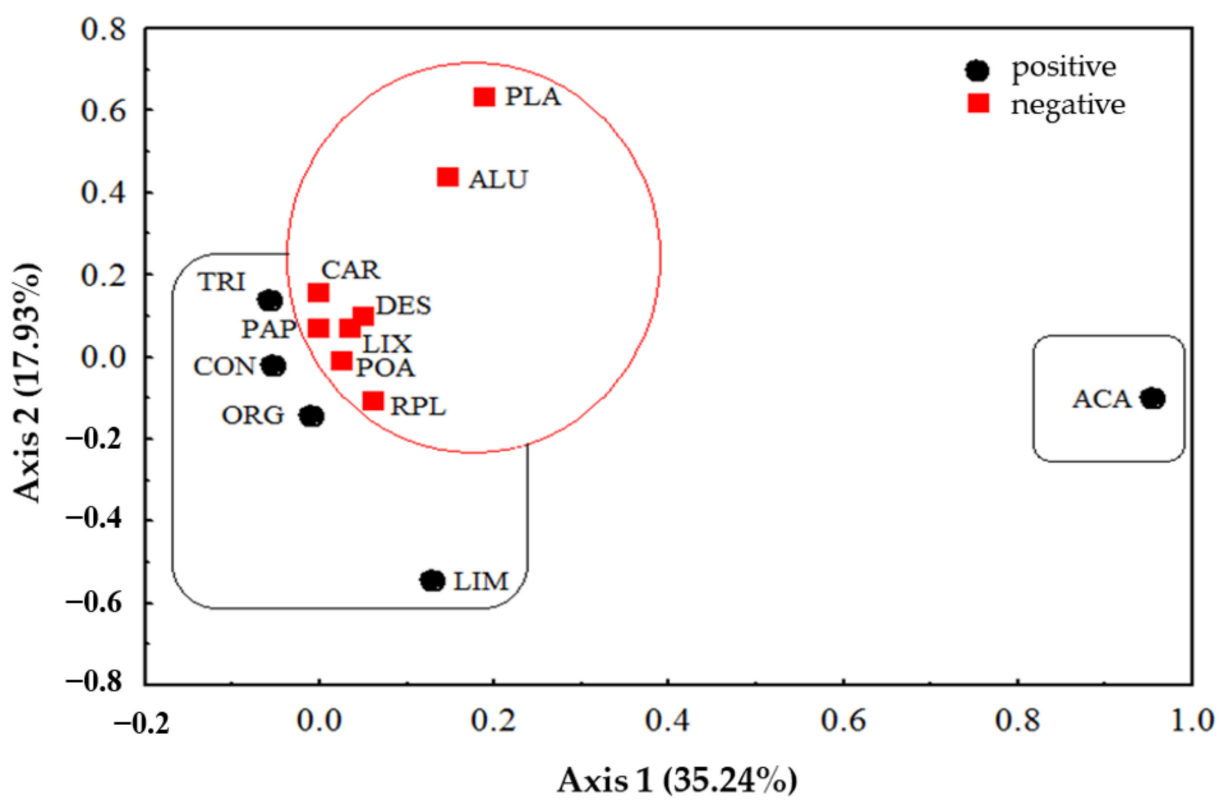

Figure 16. Ordination (by Principal Component Analysis, PCA) of respondents' responses regarding the character of the environmental impacts generated by alternative tourism in three communities of RESEX Tapajós-Arapiuns, Pará, Brazilian Amazonia. TRI = trails; PAP = paper; CON = conservation; ORG = organization; $\mathrm{LIM}=$ cleaning; $\mathrm{ACA}=$ camps; $\mathrm{PLA}=$ plants; $\mathrm{ALU}=$ aluminum; $\mathrm{CAR}=$ coal; $\mathrm{DES}=$ waste; $\mathrm{LIX}=$ trash; $\mathrm{POA}=$ water pollution; $\mathrm{RPL}=$ polluted river.

Residents demonstrated knowledge about the distinction between positive and negative environmental impacts. Therefore, this perception helps in tourism planning by the community, especially in natural areas that need permanent preservation to ensure species' survival.

\subsubsection{Perception of Acceptance of Tourism in Communities}

In the general view of the interviewees $(96.7 \%)$ and by Maripá communities $(97.8 \%)$, followed by Anã (97.1\%) and São Miguel (95.1\%), there was a demonstration for the development of tourism in their communities, mainly to increase their incomes and maintain preserved environments (Figure 17).

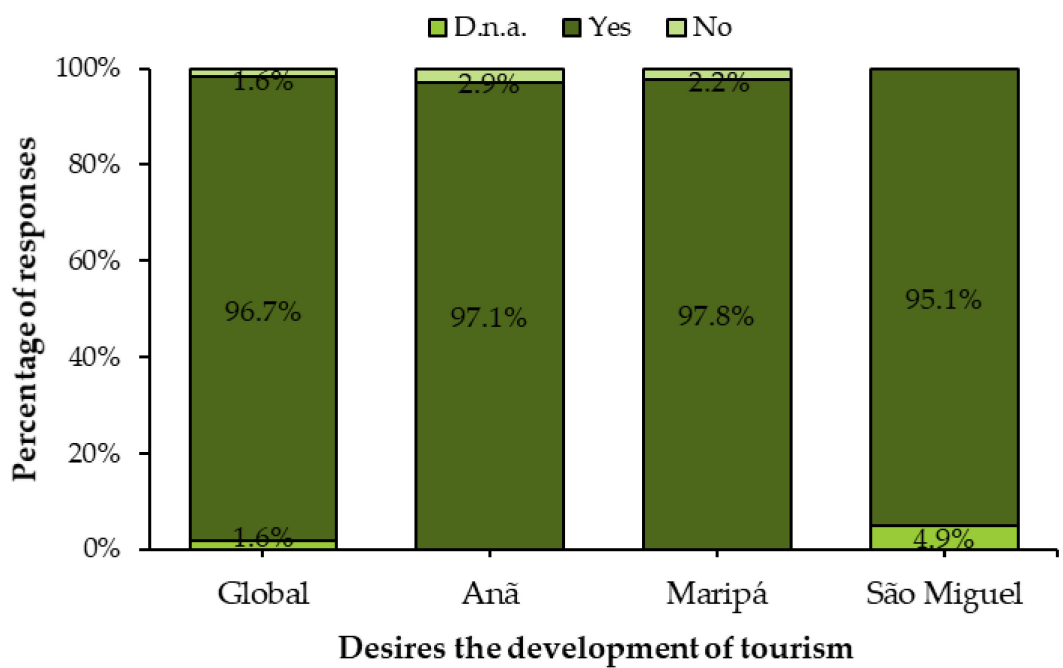

Figure 17. Global and community percentage of responses from residents of three RESEX TapajósArapiuns communities, Pará, Brazilian Amazonia, desire to develop tourism in the community. D.n.a. = did not answer. 
It is essential that there is acceptance by the residents of the development of the tourist activity, as this directly influences the treatment given to visitors [20]. The more the community feels involved, the more motivated it becomes to participate in the tourism development process. This process can increase the sense of responsibility and oversight of activities involving its natural, historical, and cultural heritage. Residents discuss what they want and what they can do to contribute to local development [126]. The interaction can increase visitors' and residents' satisfaction, thus cooperating to develop tourist destinations [127].

\section{Conclusions}

This research observed that in the three communities of RESEX Tapajós-Arapiuns, in the Brazilian Amazonia, the residents perceived more positive than negative impacts caused by alternative tourism, mainly related to income and cultural interactions between the local population and tourists.

The studied communities are difficult to access, which contributes to tourists' interest in getting to know these areas in the Brazilian Amazonia, their traditional populations, their customs, and their natural beauty.

It is suggested that the leaders involved with tourism, in these locations, experience successful examples of alternative tourism, provided through exchanges with other Conservation Units and think about how to adapt the touristic management of RESEX Tapajós-Arapiuns communities to the local reality.

Those are important changes in proposing, planning, and monitoring tourism policies for these protected areas. With little action on behalf of the government, the local infrastructure to the residents' quality of life, and comfort in receiving visitors can be compromised. Without partnerships with the State or with private companies, the community will not have an improved structure.

Finally, it is necessary to increase the scope of public policies regarding investments in infrastructure and the promotion of assistance and technical guidance for community members so that they acquire long-term autonomy to manage their sustainable tourism enterprises. This type of information is crucial for sustainable managing of protected areas and developing tourism.

Supplementary Materials: The following are available online at https:/ / www.mdpi.com/2071-1 050/13/4/2076/s1, Table S1: Roadmap for data collection of RESEX residents Tapajós-Arapiuns, Brazilian Amazonia.

Author Contributions: Conceptualization, H.M.N.M. and J.M.B.O.-J.; methodology, H.M.N.M., Q.L.d.M.G., T.A.V. and J.M.B.O.-J.; formal analysis, H.M.N.M., Q.L.d.M.G. and J.M.B.O.-J.; investigation, H.M.N.M., Q.L.d.M.G. and J.M.B.O.-J.; resources, H.M.N.M. and J.M.B.O.-J.; data curation, H.M.N.M., Q.L.d.M.G. and J.M.B.O.-J.; writing—original draft preparation, H.M.N.M., Q.L.d.M.G., T.A.V., S.M.S.d.S., A.I.d.S.A.R., and J.M.B.O.-J.; writing—review and editing, H.M.N.M., Q.L.d.M.G., T.A.V., S.M.S.d.S., A.I.d.S.A.R., and J.M.B.O.-J.; visualization, H.M.N.M., Q.L.d.M.G., T.A.V., S.M.S.d.S., A.I.d.S.A.R., and J.M.B.O.-J.; supervision, Q.L.d.M.G. and J.M.B.O.-J.; project administration, H.M.N.M. and J.M.B.O.-J.; funding acquisition, H.M.N.M. and J.M.B.O.-J. All authors have read and agreed to the published version of the manuscript.

Funding: This research received no external funding, and the APC was funded by PROPPIT/Federal University of Western of Pará through Edital 01/2020 (Programa de Apoio à Publicação Científica em Periódicos-PAPCIP).

Institutional Review Board Statement: The study was conducted according to the guidelines of the Declaration of Helsinki and approved by the Ethics Committee of Instituto Esperança de Ensino Superior-IESPES (protocol code 2.954,087, of October 2018). In addition, considering that the research was carried out in a Conservation Unit for sustainable use (equivalent to Category VI-Protected area with sustainable use of natural resources from IUCN), the project was authorized by the Sistema Nacional de Informação e Autorização de Biodiversidade-SISBIO (protocol code 63418-1, of June 2018). SISBIO is a remote service system in Brazil that allows researchers to request 
authorization to collect biological material and conduct research in federal and cave Conservation Units (Normative Instruction ICMBio No. 03/2014).

Informed Consent Statement: Informed consent was obtained from all subjects involved in the study.

Data Availability Statement: The data presented in this study are available on request from the corresponding author. The data are not publicly available due to present residents' personal information.

Acknowledgments: The authors thank the RESEX Tapajós-Arapiuns extractivists for participating in this research. We thank ICMBio (Instituto Chico Mendes de Conservação da Biodiversidade) and the following associations for logistical support: TAPAJOARA (Organização da Resex Tapajós-Arapiuns), APROANÃ (Associação de Produtores Rurais da Comunidade de Anã), ASCOPRAM (Associação Comunitária de Produtores da Comunidade de Maripá) and ASCOVISM (Associação Comunitária da Vila de São Miguel). H.M.N.M. thanks the Universidade Federal do Oeste do Pará (Ufopa) for his authorization to develop its master's activities (Ordinance No. 685/PROGEP-Ufopa of 19 April 2018). We would also like to thank the Clebson S. Freitas and Everton C. Silva for assistance in data collection.

Conflicts of Interest: The authors declare no conflict of interest.

\section{References}

1. Pérez, R.M.I.; González, M.V.G.G.; León, E.J. Recuento de la inserción del turismo alternativo en la política pública en México. Rev. Educ. 2020, 25, 5-29.

2. Christou, L.; Cyprus, N. Is it possible to combine mass tourism with alternative forms of tourism: The case of Spain, Greece, Slovenia and Croatia. J. Bus. Adm. 2012, 11, 1-8.

3. Dangi, T.B.; Petrick, J.F. Augmenting the Role of Tourism Governance in Addressing Destination Justice, Ethics, and Equity for Sustainable Community-Based Tourism. Tour. Hosp. 2021, 2, 2. [CrossRef]

4. Lucia, N.E. El Turismo Alternativo: Una opción para el desarrollo local. RevIISE 2014, 6, 9-18.

5. Weaver, D.B. Alternative tourism in Montserrat. Tour. Manag. 1995, 16, 593-614. [CrossRef]

6. Triarchi, E.; Karamanis, K. Alternative Tourism Development: A Theoretical Background. World J. Bus. Manag. 2017, 3. [CrossRef]

7. Theng, S.; Qiong, X.; Tatar, C. Mass Tourism vs Alternative Tourism? Challenges and New Positionings. Études Caribéennes 2015, 31-32. [CrossRef]

8. Secretaría de Turismo-SECTUR. Turismo Alternativo uma Nueva Forma de Hacer Turismo; Secretaría de Turismo-SECTUR: Mexico City, Mexico, 2004.

9. Guillemain, M.; Blanc, R.; Lucas, C.; Lepley, M. Ecotourism disturbance to wildfowl in protected areas: Historical, empirical and experimental approaches in the Camargue, Southern France. Biodivers. Conserv. 2007, 16, 3633-3651. [CrossRef]

10. Cases, M.O. (Ed.) Gestão de Unidades de Conservação: Compartilhando Uma Experiência de Capacitação; Realização: WWF-Brasil/IPÊInstituto de Pesquisas Ecológicas; WWF Brasil: Brasilia, Brazil, 2012.

11. Aguiar, P.C.B.; Moreau, A.M.S.S.; Fontes, E.O. Áreas Naturais Protegidas: Um breve histórico do surgimento dos Parques Nacionais e das Reservas Extrativistas. Rev. Geogr. Am. Centr. 2013, 50, 195-213.

12. Costa, F.W.D.; Furtado, M.L.S. Utilização das unidades da paisagem para a prática do ecoturismo na Reserva Extrativista Marinha de Cururupu (MA). Rev. Bras. Ecotur. 2015, 8, 482-499. [CrossRef]

13. Diário Oficial [da] República Federativa do Brasil. Lei no 9.985, de 18 de julho de 2000; Diário Oficial [da] República Federativa do Brasil: Brasilia, Brazil, 2000.

14. Peccatiello, A.F.O. Políticas públicas ambientais no Brasil: Da administração dos recursos naturais (1930) à criação do Sistema Nacional de Unidades de Conservação (2000). Desenvolv. Meio Ambiente 2011, 24, 71-82. [CrossRef]

15. Freire, P.M.O.; Almeida, F.A.B. Ecoturismo, educação ambiental crítica e formação de sujeitos ecológicos: Convergências e desafios. Rev. Bras. Ecotur. 2018, 11, 561-587. [CrossRef]

16. Leme, F.B.M.; Neves, S.C. Dos ecos do turismo aos ecos da paisagem: Análises das tendências do ecoturismo e a percepção de suas paisagens. PASOS Rev. Tur. Patrim. Cult. 2007, 5, 209-223. [CrossRef]

17. Dias, R. Planejamento Do Turismo: Política E Desenvolvimento Do Turismo No Brasil; Atlas: São Paulo, Brazil, 2003.

18. Pereira, T.F.; Campos, J.O.; Pereira, M.R.; Dos, S.; Lima, V.R.P. Ecoturismo e os impactos ambientais no Parque Estadual Mata do Pau-Ferro, Areia, Paraíba. GeoTemas 2019, 9, 128-143. [CrossRef]

19. Leung, Y.; Spenceley, A.; Hvenegaard, G.; Buckley, R. Tourism and Visitor Management in Protected Areas: Guidelines towards Sustainability, 1st ed.; IUCN: Gland, Switzerland, 2018; p. 120.

20. Carvalho, S.M.S. A Percepção do Turismo por Parte da Comunidade Local e dos Turistas no Município de Cajueiro da Praia-PI. Rev. Tur. Análise 2010, 21, 470-493. [CrossRef]

21. Ruoso, D. A percepção climática população urbana de Santa Cruz do Sul—RS. RAEGA Espaço Geogr. Análise 2012, 25 , 64-91. [CrossRef]

22. Oliveira, E.S. Percepção dos autóctones em relação à economia, meio ambiente e ao turismo em Ilhéus-BA. In SEMINTUR, 4., Caxias do Sul.; Universidade Caixas do Sul: Caxias do Sul, Brazil, 2006. 
23. Milagres, V.; Souza, E.; Souza, L. Percepção ambiental no distrito de Taquaruçu, município de Palmas (TO): A relação dos moradores com as transformações da paisagem ao longo da história local. Cad. Virtual Tur. 2010, 10, 1-14.

24. Souza, T.D.; Thapa, B.; Rodrigues, C.; Imori, D. Economic impacts of tourism in protected areas of Brazil. J. Sustain. Tour. 2018, 27, 735-749.

25. Wallace, G.N.; Pierce, S.M. An evaluation of ecotourism in Amazonas, Brazil. Ann. Tour. Res. 1996, 23, 843-873. [CrossRef]

26. Brasil. Decreto s/n de 6 de Novembro de 1998. Diário Oficial [da] República Federativa do Brasil, Brasília, 6 de Novembro de 1998; Presidência da República Brasil: Brasilia, Brazil, 1998.

27. Martorano, L.G.; Pereira, L.C.; Nechet, D. Tipologia climática do Estado do Pará-Adaptação do método Köppen. Bol. Geog. Teor. $1993,23,45-46$.

28. INMET Instituto Nacional de Meteorologia. Normas Climatológicas. Available online: www.inmet.gov.br. (accessed on 10 July 2019$)$.

29. Tsukamoto, F.A.T.; Campos, M.N.; Vasconcelos, L.M.R.; Matos, S.P. Diversidade florística de um parque zoobotânico no município de Santarém-Pará. In Proceedings of the VIII Congresso de Ecologia do Brasil, Caxambu, Brazil, 23-28 September 2007.

30. Moraes, B.C.; Costa, J.M.N.; Costa, A.C.L.; Costa, M.H. Variação espacial e temporal da precipitação no estado do Pará. Acta Amaz. 2005, 35, 207-214. [CrossRef]

31. ICMBIO Instituto Chico Mendes de Conservação da Biodiversidade. Plano de Manejo da RESEX Tapajós Arapiuns; ICMBIO: Brasilia, Brazil, 2014; Volume 1: Diagnóstico.

32. ICMBIO Instituto Chico Mendes de Conservação da Biodiversidade. Plano de Manejo da RESEX Tapajós Arapiuns; ICMBIO: Brasilia, Brazil, 2014; Volume 3: Anexos.

33. EMBRAPA Empresa Brasileira de Pesquisa Agropecuária. Sistema Brasileiro de Classificação de Solos, 3rd ed.; Embrapa/CNPS: Rio de Janeiro, Brazil, 2013.

34. Brasil, Ministério das Minas e Energia. Departamento Nacional da Produção Mineral: Projeto RADAM. Levantamento de recursos naturais. In Tapajós: Geologia, Geomorfologia, Solos, Vegetação e Uso Potencial da Terra; Ministério das Minas e Energia: Rio de Janeiro, Brazil, 1975; Volume 7.

35. PSA (Projeto Saúde e Alegria). Coleção Prazer em Conhecer: Comunidades da Reserva Extrativista Tapajós-Arapiuns; CEAPS: Santarém, Brazil, 2014.

36. Ap, J. Residents' perceptions on tourism impacts. Ann. Tour. Res. 1992, 19, 665-690. [CrossRef]

37. Jennings, G.R. Interviewing: A Focus on Qualitative Techniques. In Tourism Research Methods: Intergrating Theory with Practice; Brent, W.R., Peter, B., Catherine, P., Eds.; CABI Publishing: Wallingford, UK, 2005; pp. 99-115.

38. Paunović, I.; Jovanović, V. Implementation of Sustainable Tourism in the German Alps: A Case Study. Sustainability 2017, 9, 226. [CrossRef]

39. Smith, S.L.J. Practical Tourism Research; CABI: Wallingford, UK, 2012.

40. Oliveira, E.S. Impactos Socioambientais e Econômicos do Turismo e Suas Repercussões no Desenvolvimento Local: O Caso de Itacaré-Bahia. Master's Thesis, Universidade Estadual de Santa Cruz, Ilhéus, Brazil, 2008.

41. Vinuto, J. A amostragem em bola de neve na pesquisa qualitativa: Um debate em aberto. Temáticas 2014, 22, $203-220$.

42. Veiga, L.; Gondim, S.M.G. A utilização de métodos qualitativos na Ciência Política e não Marketing Político. Opinião Públ. 2001, 7, 1-15. [CrossRef]

43. Baldin, N.; Munhoz, E.M.B. Snowball (Bola de Neve): Uma técnica metodológica para pesquisa em Educação Ambiental Comunitária. In Proceedings of the X EDUCERE e I SIRSSE, Curitiba, Brazil, 7-10 November 2011; Congresso Nacional de Educação. Curitiba: Champagnat-Editora PUCPR, v. 1. pp. 329-341.

44. Martins, D.P. A percepção como método para trabalhos em educação ambiental: O caso de uma comunidade de Porto Alegre-RS. In IBEAS-Instituto Brasileiro de Estudos Ambientais. In Proceedings of the II Congresso Brasileiro de Gestão Ambiental, Londrina, Brazil, 6-9 November 2011.

45. Silvano, R.A.M.; Silva, A.L.; Ceroni, M.; Begossi, A. Contributions of ethnobiology to the conservation of tropical rivers and streams. Aquat. Conserv. Mar. Freshw. Ecosyst. 2008, 18, 241-260. [CrossRef]

46. Jackson, D.A. Stopping rules in principal components analysis: A comparison of heuristical and statistical approaches. Ecology 1993, 74, 2204-2214. [CrossRef]

47. R Development Core Team. R: A Language and Environment for Statistical Computing; R Foundation for Statistical Computing: Vienna, Austria, 2011. Available online: http:/ /www.R-project.org/. (accessed on 12 December 2018).

48. Di Ciommo, R.C. Pescadoras e pescadores: A questão da equidade de gênero em uma Reserva Extrativista marinha. Ambient. Soc. 2007, 10, 151-163. [CrossRef]

49. Silva, J.T.; Braga, T.M.P. Caracterização da Pesca na comunidade de Surucuá (RESEX Tapajós-Arapiuns). Biota Amaz. 2016, 6, 55-62. [CrossRef]

50. IBGE, Instituto Brasileiro de Geografia e Estatística. Censo Demográfico 2010; IBGE: Rio de Janeiro, Brazil, 2010. Available online: http:/ / www.ibge.gov.br (accessed on 17 July 2019).

51. Escada, M.I.S.; Amaral, S.; Dal'Asta, A.P.; Soares, F.R.; Andrade Neto, P.R.; Pinho, C.M.D.; Medeiros, L.C.C.; Camilotti, V.L.; Santos, J.N.A.; Ferreira, V.C. Estrutura, Serviços e Conectividade das Comunidades Ribeirinhas do Arapiuns, PA. Pesquisa de Campo Jun de 2012, Relatório Técnico de Atividade de Pesquisa do INPE; INPE: São José dos Campos, Brazil, 2012.

52. Costa, E.R.; Sobrinho, M.V. Unidades de Conservação de Uso Sustentável e agricultura familiar na Amazônia: Conflitos e desafios na Floresta Estadual do Amapá. Rev. GeoAmaz. 2015, 3, 97-116. [CrossRef] 
53. Guerreiro, Q.L.M.; Oliveira Júnior, R.C.; Santos, G.R.; Ruivo, M.L.P.; Beldini, T.P.; Carvalho, E.J.M.; da Silva, K.E.; Guedes, M.C.; Santos, P.R.B. Spatial variability of soil physical and chemical aspects in a Brazil nut tree stand in the Brazilian Amazon. Afr. J. Agric. Res. 2017, 12, 237-250.

54. Silva, L.J.S.; Meneghetti, G.A.; Emídio, K.; Brito, V.F.S. Realidade socioeconômica das comunidades extrativistas da RDS PiagaçuPurus: Reflexões sobre os condicionantes da adoção de tecnologias como estratégia de desenvolvimento rural. In Seminário Internacional de Ciências do Ambiente e Sustentabilidade na Amazônia 4; Anais Embrapa Amazônia Ocidental: Manaus, Brazil, 2016; p. 326.

55. Hoffmann, R.; Ney, M.G. Desigualdade, escolaridade e rendimentos na agricultura, indústria e serviços, de 1992 a 2002. Econ. Soc. 2004, 13, 51-79.

56. Anjos, F.S.; Niederle, P.A.; Caldas, N.V. Pluriatividade e pesca artesanal: O caso da Colônia Z-3 em Pelotas, RS. Rev. Soc. Debate 2004, 10, 9-42.

57. Alves, R.J.M.; Pontes, A.N.; Gutjahr, A.L.N. Caracterização socioeconômica de comunidades rurais amazônicas do estado do Pará, Brasil. Observatório de la economia latino-americana. Rev. Eumednet 2015, 210, 6.

58. Fearnside, P.M. Extractive Reserves in Brazilian Amazonia: An opportunity to maintain tropical rain forest under sustainable use. BioScience 1989, 39, 387-393. [CrossRef]

59. Geisler, C.; Silberling, L. Extractive Reserves as Alternative Land Reform: Amazonia and Appalachia Compared. Agric. Hum. Values 1992, 9, 58-70. [CrossRef]

60. Freitas, J.S.; Farias Filho, M.C.; Homma, A.K.O.; Mathis, A. The unsustainability of Extractive Reserves in the Amazon: Socioeconomic demands versus environmental conservation. Desenvolve 2020, 9, 9-27. [CrossRef]

61. Barros, Q.S.; Martins, B.C.; Oliveira, É.K.; Félix, M.A.C. Perfil socioeconômico dos moradores da Reserva Extrativista do Alto Juruá-Acre. Cad. Agroecol. 2015, 10, 2236-7934.

62. Zeidemann, V.; Kainer, K.; Staudhammer, C. Heterogeneity in NTFP quality, access and management shape benefit distribution in an Amazonian extractive reserve. Environ. Conserv. 2014, 41, 242-252. [CrossRef]

63. Wadt, L.H.O.; Kainer, K.A.; Gomes-Silva, D.A.P. Population structure and nut yield of a Bertholletia excelsa stand in Southwestern Amazonia. For. Ecol. Manag. 2005, 211, 371-384. [CrossRef]

64. Vasconcelos, M.C.; Vieira, T.A.; Corrêa, K.C. Calidad de vida de habitantes de una comunidad rural de dique en Santarém, Pará. Interfaces Rev. Ext. UFMG 2017, 5, 148-156.

65. Salvato, M.A.; Ferreira, P.C.G.; Duarte, A.J.M. O Impacto da escolaridade sobre a distribuição de renda. Estud. Econ. 2010, 40, 753-791. [CrossRef]

66. Sousa, A.M.P.; Pontes, B.S.; Silva, M.J.S.; Vieira, T.A. Cooperativism in forest communities in the Amazon: What do non-members say? Ambiente Soc. 2019, 22, e01201. [CrossRef]

67. Santos, C.R.B.; Magalhães, R. Pobreza e Política Social: A implementação de programas complementares do Programa Bolsa Família. Ciência Saúde Colet. 2012, 17, 1215-1224. [CrossRef] [PubMed]

68. Guedes, G.R.; Costa, S.; Brondizio, E. Revisiting the Urban Hierarchy Approach in the Brazilian Amazon: A Multilevel Model Using Multivariate Fuzzy Cluster Methodology. Popul. Environ. 2009, 30, 159-192. [CrossRef] [PubMed]

69. Ferreira, P.R. Após o regatão, o rádio e a televisão. In Encontro Nacional da Rede Alfredo de Carvalho, 3, 2005; Alcar: Novo Hamburgo, Brazil, 2005. Available online: http:/ / paginas.ufrgs.br/alcar/encontros-nacionais-1/3o-encontro-2005-1 (accessed on 2 June 2019).

70. Dal'Asta, A.P.; Amaral, S.; Monteiro, A.M.V. O Rio e as cidades: Uma análise exploratória de dependências e alcances das comunidades do Arapiuns (Pará-Brasil) e da formação do urbano na Amazônia. Rev. Espin. 2014, 3, $98-109$.

71. Santos, M.A.M.T. A Produção do Sucesso na Educação de Jovens e Adultos: O Caso de uma Escola Pública em Brazlândia. Master's Thesis, Faculdade de Educação, Universidade de Brasília, Brasilia, Brazil, 2007.

72. Souza, J.C.R. O Currículo da Escola de Várzea e o Ensino de Geografia no Município de Parintins. Master's Thesis, Faculdade de Educação/Universidade Federal do Amazonas, UFAM, Manaus, Brazil, 2006.

73. Instituto Trata Brasil. Associação Brasileira das Concessionárias Privadas de Serviços Públicos de água e Esgoto. Benefícios Econômicos e Sociais da Expansão do Saneamento no Brasil. São Paulo. 2018. Available online: www.tratabrasil.org.br. (accessed on 20 September 2019).

74. Oliveira, G.; Scazufca, P.; Pires, R.C. Ranking do Saneamento: Instituto Trata Brasil: 2018; GO Associados: São Paulo, Brazil, 2018. Available online: http://www.tratabrasil.org.br/estudos/estudos-itb/itb/ranking-do-saneamento-2018. (accessed on 18 July 2019).

75. Galvão Júnior, A.C. Acesso a Água nas Regiões Norte e Nordeste do Brasil: Desafios e Perspectivas; Instituto Trata Brasil: São Paulo, Brazil, 2018.

76. Freitas, S.J.; Amaral, V.S.; Silva, D.C.C.; Rodrigues, M. O Falido Modelo de Unidades de Conservação de Uso Sustentável da Amazônia. In Proceedings of the VII Seminário Internacional sobre Desenvolvimento Regional, Universidade de Santa Cruz do Sul, Santa Cruz do Sul, Brazil, 9-11 September 2015; pp. 1-18.

77. Bentes, A.J.M.; Monteiro, R.N.; Vieira, T.A. Socioeconomia e Gestão florestal no Projeto de Assentamento Moju I e II, Pará, Brasil. Rev. Retratos Assentamentos 2020, 23, 55-90.

78. Orth, D.; Debetir, E. (Eds.) Unidades de Conservação-Gestão e Conflitos; Insular: Florianópolis, Brazil, 2007.

79. Brasil - ICMBIO; Instrução Normativa nº 7, de 21 de Dezembro de 2017; DOU: Brasilia, Brazil, 2017. 
80. Simonetti, S.R.; Nascimento, E.P. Uso público em unidades de conservação: Fragilidades e oportunidades para o turismo na utilização dos serviços ecossistêmicos. Somanlu 2012, 12, 173-190.

81. Georgakopoulou, S.; Delitheou, V. The Contribution of Alternative Forms of Tourism in Sustainable Tourism Development: The Case of the Island of Kalymnos. In Cultural and Tourism Innovation in the Digital Era; Springer Proceedings in Business and Economics; Katsoni, V., Spyriadis, T., Eds.; Springer: Cham, Switzerland, 2020. [CrossRef]

82. Gursoy, D.; Christina, G.C.; Dyer, P. Locals' Attitudes toward Mass and Alternative Tourism: The Case of Sunshine Coast, Australia. J. Travel Res. 2010, 49, 381-394. [CrossRef]

83. Smith, V.; Eadington, W. Tourism Alternatives: Potentials and Problems in the Development of Tourism; University of Pennsylvania Press: Philadelphia, PA, USA, 1992.

84. Brito, B.R. O turismo e o viajante: Contributos para a conceptualização do turismo alternativo e responsável. In Proceedings of the Congresso Português de Sociologia-Sociedade Portuguesa, 4. Actas Passados Recentes, Futuros Próximos, Coimbra, Portugal, 17-19 April 2000. Available online: http:/ / www.aps.pt/cms/docs_prv/docs/DPR462dea1a49422_1.PDF (accessed on 2 August 2019).

85. Ibáñez, R.; Villalobos, I.R. Tipologías y antecedentes de la atividade turística: Turismo tradicional y turismo alternativo. In Meio Ambiente e Politica Turística em México. Tomo I: Ecología, Biodiversidade y Desarrollo Turístico; Ivanova, A., Ibañéz, R., Eds.; Universidad Autónoma de Baja Califórnia Sur: La Paz, Mexico, 2012.

86. Assis, G.C.; Peixoto, R.C.D. O turismo é uma dádiva? Uma "etnografia das trocas" e a oferta da experiência "chamada" Turismo de Base Comunitária em Anã/Santarém/Pará. Rev. Bras. Tur. 2019, 13, 140-160. [CrossRef]

87. Russel, P. Community-based tourism. Travel Tour. Anal. 2000, 5, 89-116.

88. Peralta, N.; Vieira, F.S.; Ozorio, R.Z. Gestão participativa da pousada Uacari: Um processo em construção. In Lições e Reflexões Sobre o Turismo de Base Comunitária na Reserva Mamirauá; Ozorio, R.Z., Bezerra, N.P., Vieira, F.S., Eds.; Instituto de Desenvolvimento Sustentável Mamirauá IDSM: Tefé, Brazil, 2016.

89. Lickorish, J.; Jenkins, C.L. Introdução ao Turismo; Elsevier: Rio de Janeiro, Brazil, 2000.

90. Oliveira, R.E.; Vasquez, G.H. Impactos Socioeconômicos, Culturais e Ambientais na Percepção de Moradores e Turistas de Ubatuba-SP. Rev. Nac. Gerenc. Cid. 2018, 6, 35-50. [CrossRef]

91. Mendoza Ontiveros, M.M.; González Sosa, J.C. Impactos socioculturales del turismo en el Centro Integralmente Planeado Loreto, Baja California Sur, México. Percepción de los residentes locales. Teoría Prax. 2014, 16, 117-146. [CrossRef]

92. OMT. Introdução ao Turismo; OMT Roca: São Paulo, Brazil, 2001.

93. Beni, M.C. Análise Estrutural do Turismo, 13th ed.; SENAC/SP: São Paulo, Brazil, 2017.

94. Stori, F.T. Pescadores e Turistas em uma Área Marinha Protegida: Uma Contribuição ao Planejamento da Reserva Extrativista Marinha da Ponta do Corumbau, Bahia-Brasil. Master's Thesis, Universidade Federal de São Carlos, Programa de Pós-graduação em Ecologia e Recursos Naturais, São Paulo, Brazil, 2005.

95. Neher, T.P.; Soupir, M.L.; Kanwar, R.S. Lake Atitlan: A Review of the Food, Energy, and Water Sustainability of a Mountain Lake in Guatemala. Sustainability 2021, 13, 515. [CrossRef]

96. Sánchez, L.E. Avaliação de Impacto Ambiental: Conceitos E Métodos, 2nd ed.; Oficina de Textos: São Paulo, Brazil, 2013.

97. Gursoy, D.; Jurowski, C.; Uysal, M. Resident Attitudes: A Strutural Modeling Approach. Ann. Tour. Res. 2002, 29, 79-105. [CrossRef]

98. Pires, E.V. Impactos sócio-culturais do turismo sobre as comunidades receptoras: Uma análise conceitual. Cad. Virtual Tur. 2004, $4,14-18$.

99. Oliveira, J.C.; Lemos, T.A.; Campos, D.P.F.; Costa, S.S.; Guerreiro, Q.L.M. Identificação de aspectos e impactos ambientais em turismo de praia e sol, no município de Santarém-Pa, Brasil. In Proceedings of the I Congresso Sul-Americano de resíduos sólidos IBEAS-Instituto Brasileiro de Estudos Ambientais, Gramado, Brazil, 12-14 June 2018.

100. Alves, G.L.M.; Granado, D.C. Turismo e impactos ambientais no balneário municipal de Rosana-SP. Colloq. Hum. 2015, 12, 894-902. [CrossRef]

101. Ozorio, R.Z.; Peralta, N.; Vieira, F.S. (Eds.) Lições e Reflexões sobre o Turismo de Base Comunitária na Reserva Mamirauá; Instituto de Desenvolvimento Sustentável Mamirauá IDSM: Tefé, Brazil, 2016; p. 296.

102. Spenceley, A.; Kohl, J.; Mcarthur, S.; Myles, P.; Notarianni, M.; Paleczny, D.; Pickering, C.; Turner, K.; Bhutia, P.; Worboys, G.L. Visitor management. In Protected Area Governance and Management; Worboys, G., Lockwood, M., Kothari, A., Feary, S., Pulsford, I., Eds.; Australian National University Press: Canberra, ACT, Australia, 2015; pp. 715-750.

103. Blanco, E.S. O turismo rural em áreas de agricultura familiar: A "novas ruralidades" e a sustentabilidade do desenvolvimento local. Cad. Virtual Tur. 2004, 4, 44-49.

104. Mayer, M.; Müller, M.; Wolteringa, M.; Arnegger, J.; Job, H. The economic impact of tourism in six German national parks. Landsc. Urban Plann. 2010, 97, 73-82. [CrossRef]

105. Liu, Z. Sustainable Tourism Development: A Critique. J. Sustain. Tour. 2003, 11, 459-475. [CrossRef]

106. Ignarra, L.R. Fundamentos do Turismo, 3rd ed.; Cengage Learning: São Paulo, Brazil; Editora SENAC: Rio de Janeiro, Brazil, 2013.

107. Nuñes, T. Los estudios del turismo dentro de una perspectiva antropológica. In Anfitriones E Invitados: Antropología Del Turismo; Smith, V.L., Ed.; Endymión: Madrid, Spain, 1992.

108. Lage, B.H.G.; Milone, P.C. Economia do Turismo, 7th ed.; Atlas: São Paulo, Brazil, 2009.

109. Belsoy, J.; Korir, J.; Yego, J. Environmental Impacts of Tourism in Protected Areas. J. Environ. Earth Sci. $2010,2,64-73$. 
110. Eagles, P.; McCool, S.; Haynes, C. Sustainable Tourism in Protected Areas: Guidelines for Planning and Management; IUCN: Gland, Switzerland; Cambridge, UK, 2002.

111. SEBRAE. Cadernos de Atrativos Turísticos; Sebrae: São Paulo, Brazil, 2016.

112. Hall, C.M. Planejamento Turístico: Políticas, Processos E Relacionamentos; Contexto: São Paulo, Brazil, 2004.

113. Buckley, R. Draft Principles for Tourism in Protected Areas. J. Ecotour. 2002, 1, 75-80. [CrossRef]

114. Spenceley, A. (Ed.) . Responsible Tourism: Critical Issues for Conservation and Development; Earthscan: London, UK, 2008.

115. Liu, W.; Vogt, C.A.; Luo, J.; He, G.; Frank, K.A.; Liu, J. Drivers and Socioeconomic Impacts of Tourism Participation in Protected Areas. PLoS ONE 2012, 7, e35420. [CrossRef] [PubMed]

116. Hoeffel, J.L.; Fadini, A.A.B.; Machado, M.K.; Reis, J.C. Trajetórias do Jaguary-Unidades de conservação, percepção ambiental e turismo: Um estudo na APA do Sistema Cantareira, São Paulo. Ambiente Soc. 2008, 11, 131-148. [CrossRef]

117. Fandé, M.B.; Pereira, V.F.G.C. Impactos ambientais do turismo: Um estudo sobre a percepção de moradores e turistas no Município de Paraty-RJ. Rev. Eletr. Gest. Educ. Tecnol. Ambiental REGET 2014, 18, 1170-1178. [CrossRef]

118. Soares, I.A.; Medeiros, C.S.C.; Filho, A.S. Análise de paisagens turísticas da praia de Ponta Negra (Natal/RN) com a utilização de indicadores de qualidade visual: Uma contribuição para o turismo sustentável. Holos 2014, 1, 228-246. [CrossRef]

119. Paiva, B.C.A. Impactos ambientais em Unidades de Conservação: Parque Nacional de Anavilhanas na visão dos profissionais envolvidos com a visitação. Rev. Bras. Ecotur. 2019, 12, 67-77. [CrossRef]

120. Kiyotani, I.B. Paisagem: As modificações através do turismo de segundas residências nas praias de Jacumã, Carapibus e Tabatinga-Conde/PB, Brasil. In Anais Do VII Seminário de Pesquisa Do Mercosul: Turismo E Paisagem Relação Complexa; Universidade Federal da Paraíba: João Pessoa, Brazil, 2012.

121. Cordeiro, I.; Körössy, N. Quando as políticas públicas de turismo sustentável ignoram a dimensão social: Reflexões a partir do estudo de caso de Fernando de Noronha (PE). Cad. Virtual Tur. 2018, 18, 42-58. [CrossRef]

122. Sander, B. The importance of education in ecotourism ventures: Lessons from Rara Avis ecolodge, Costa Rica. Int. J. Sustain. Soc. 2012, 4, 389-404. [CrossRef]

123. Wearing, S.; Neil, J. Ecoturismo: Impactos, Potencialidades and Possibilidades; Manole: Sao Paulo, Brazil, 2014.

124. Harlow, S.; Pomfret, G. Evolving Environmental Tourism Experiences in Zambia. J. Ecotour. 2007, 6, 184-209. [CrossRef]

125. UNESCO-UNEP. International Strategy for Action in the Field of Environmental Education and Training for the 1990; UNESCO: Nairobi, Kenia; Paris, France, 1987.

126. Magalhães, C.F. Diretrizes Para O Turismo Sustentável Em Municípios; Roca: São Paulo, Brazil, 2002.

127. Eusébio, C.; Carneiro, M.J. A importância da percepção dos residentes dos impactes do turismo e da interacção residente-visitante no desenvolvimento dos destinos turísticos. In Universidade de Aveiro. In Proceedings of the 7th Workshop-APDR, XXXVI Reunión de Estudios Regionales-AECR, Badajoz-Elvas, Spain, 18-19 November 2010. 